Volume 65

Issue 5 Symposia

$1-29-2021$

\title{
Women Law Professors: The First Century (1896-1996)
}

Catherine J. Lanctot

Follow this and additional works at: https://digitalcommons.law.villanova.edu/vlr

Part of the Law and Gender Commons

\section{Recommended Citation}

Catherine J. Lanctot, Women Law Professors: The First Century (1896-1996), 65 Vill. L. Rev. 933 (2021). Available at: https://digitalcommons.law.villanova.edu/vlr/vol65/iss5/1

This Symposia is brought to you for free and open access by Villanova University Charles Widger School of Law Digital Repository. It has been accepted for inclusion in Villanova Law Review by an authorized editor of Villanova University Charles Widger School of Law Digital Repository. 


\title{
VILLANOVA LAW REVIEW
}

\section{Norman J. Shachoy Symposium: Gender EQuity in LaW SCHOols}

WOMEN LAW PROFESSORS: THE FIRST CENTURY (1896-1996)

\author{
Catherine J. Lanctot*
}

$\mathrm{O}$ N October 25, 2019, the Villanova Law Review held its annual Norman J. Shachoy Symposium on the topic of Gender Equity in Law Schools. Each of the four panels addressed a different aspect of this broad area, providing unique insights into a problem that continues to plague legal education. ${ }^{1}$ This Issue of the Law Review reflects not only some of

* Professor of Law, Villanova University Charles Widger School of Law. This Symposium was made possible by the generosity of Norman J. Shachoy, the Law School Admission Council, and the Anne Welsh McNulty Institute for Women's Leadership. I am grateful for the support of Dean Mark Alexander and all those in the Law School who contributed to the success of this Symposium. A special thank you to all the women of Villanova Law-students, staff, and faculty-who made this a true community event.

1. After the keynote address by Meera Deo, Professor of Law, Thomas Jefferson School of Law, the first panel addressed the topic "Defining The Problem," and consisted of Teri McMurtry-Chubb, Professor of Law, Mercer University School of Law, Dara Purvis, Associate Dean for Diversity and Inclusion, Penn State Law, and Sean M. Scott, Professor of Law, Loyola Marymount University, Loyola Law School Los Angeles. The second panel addressed the topic "Structural Barriers," and consisted of Mary Beth Beazley, Professor of Law, UNLV William S. Boyd School of Law, Deborah L. Borman, Assistant Professor of Law, UA Little Rock William H. Bowen School of Law, and Kristen Tiscione, Professor of Law, Legal Practice, Georgetown Law. The lunch panel featured three speakers on the Denver Equal Pay Litigation: Kris McDaniel-Miccio, Professor, Sturm College of Law, Charlotte N. Sweeney, Founding Member and Attorney, Sweeney \& Bechtold, LLC, and Celia Taylor, Professor and Director of International Legal Studies Program, Nanda Chair, Sturm College of Law. The third panel focused on the topic "Solutions," and consisted of Dr. Terri Boyer '95 CLAS, Founding Director, Anne Welsh McNulty Institute for Women's Leadership, Andrea A. Curcio, Professor of Law, Georgia State University College of Law, Mary A. Lynch, Kate Stoneman Chair in Law and Democracy, Albany Law School, and Constance Z. Wagner, Professor, Saint Louis University School of Law. Finally, the Symposium concluded with a presentation by several current and former law deans: Susan Duncan, Dean and Professor of Law, University of Mississippi School of Law, Risa L. Goluboff, Dean, Arnold H. Leon Professor of Law and Professor of History, University of Virginia School of Law, Jennifer Rosato Perea, Dean and Professor of Law, DePaul University College of Law, Kellye Testy, President, and CEO, Law School Admis- 
the presentations made at the Symposium, but also contains additional contributions by other scholars.

As we planned for the Symposium that is the subject of this issue, I had numerous conversations with other female law professors, both at Villanova Law School and elsewhere. One common refrain in these conversations was to ask: "How can it be that, in 2019, we still have not rectified these issues of gender equity in law schools? I thought that by now our problems would have been solved." Indeed, many of us believed that changing attitudes toward gender roles, coupled with sheer demographic change in the number of women in legal academia, would largely have eradicated the inequality in treatment that is the subject of this Symposium.

Before we can undertake the necessary steps to ensure full equality for women in law teaching, it might benefit us to look backward. It is important to remember that law schools admitted women into the professoriate reluctantly, largely because of the threat of legal action in the early 1970 s, and the attitudes that required such drastic action persisted for many years. An examination of how women first entered the profession, the hurdles they tried to overcome, and how changes over time have reduced, but not eliminated, unequal treatment, could better inform our efforts going forward. This Article is a first step in presenting this history.

My motivation in pulling this material together came initially because there was no one source containing a basic overview and chronology of women in legal academia that could be used as a starting point. Much work has been done on many discrete topics relating to the history of women in law schools, and there is much more work that could be done. Although I have tried in this Article to present as much information as I could for an initial examination of the topic, I remain painfully aware that there are many areas that merit further elaboration. One way to accomplish that objective would be to redouble the effort to obtain oral histories from women who are retired or approaching the end of their careers, as these reports have been invaluable in shaping the material that follows.

I hope that this Article will serve as a starting point for a broader examination of the past experience of women in legal education, as we commit ourselves to making changes for a more equitable future.

\section{I. "On the Fingers of One Hand": 1896-1950}

The first American women to teach law students were Ellen Spencer Mussey and Emma Gillett, who began training a handful of women in Mussey's District of Columbia law office in 1896, at a time when women lawyers were a rarity at best. About twenty-five years earlier, in 1870, the United

sion Council and Dean's Distinguished Fellow, Villanova University Charles Widger School of Law, moderated by Mark C. Alexander, Arthur J. Kania Dean and Professor of Law, Villanova University Charles Widger School of Law. I am grateful to all participants for giving us their insights on such an important topic. 
States Supreme Court had explicitly held that women could not claim any right to be admitted to the practice of law under the recently adopted Fourteenth Amendment. The plaintiff in that lawsuit was Myra Bradwell (1831-1893), the daughter of abolitionists and a former schoolteacher who later married a lawyer and became the owner, editor, and publisher of the Chicago Legal News. ${ }^{2}$ Bradwell decided to become a member of the Illinois bar in order to assist her husband in his law practice. Although she passed the bar examination in 1869, she was denied admission because she was a woman.

The Supreme Court dismissed Bradwell's claim that this denial violated the Privileges or Immunities Clause in Bradwell v. Illinois, ${ }^{3}$ relying on the Court's recent decision in the Slaughter-House Cases to announce that the Fourteenth Amendment did not protect any claimed right to practice law. ${ }^{4}$ But it was the infamous concurrence of Justice Joseph Bradley, joined by Justices Noah Swayne and Stephen J. Field, that asserted a more explicit objection to admitting women to the bar:

The natural and proper timidity and delicacy which belongs to the female sex evidently unfits it for many of the occupations of civil life. The constitution of the family organization, which is founded in the divine ordinance, as well as in the nature of things, indicates the domestic sphere as that which properly belongs to the domain and functions of womanhood. ... It is true that many women are unmarried and not affected by any of the duties, complications, and incapacities arising out of the married state, but these are exceptions to the general rule. The paramount destiny and mission of woman are to fulfil the noble and benign offices of wife and mother. This is the law of the Creator. ${ }^{5}$

Bradwell never reapplied for admission to the bar, even though the Illinois legislature apparently chose to violate the law of the Creator when it lifted the ban on women lawyers in $1872 .{ }^{6}$

2. See Carol Sanger, Curriculum Vitae (Feminae): Biography and Early American Women Lawyers, America's First Woman Lawyer: The Biography of Myra Bradwell. By Jane M. Friedman., 46 Stan. L. Rev. 1245 (1994). Bradwell required a special charter from the Illinois legislature to permit her to own the company, because she was a married woman. Id. at 1259. Her flourishing company also published legal briefs, legal forms, and law books, which became of particular benefit when the Great Chicago Fire of 1871 destroyed the records of the Chicago bar. Id.

3. 83 U.S. 130 (1872).

4. See id.

5. Id. at 141 (Bradley, J., concurring). The only dissenter was Bradwell's distant relative, Chief Justice Salmon Chase. See Sanger, supra note 2, at 1259.

6. See Sanger, supra note 2, at 1260. Bradwell oversaw her prosperous publishing business and pursued a number of legal reforms "in areas central to women's equality - the abolition of coverture, the establishment of maternal custody rights, and putting an end to the involuntary commitment of women to mental institutions by their husbands." Id. 
Bradwell's contemporary, Belva Lockwood (1830-1917), took a different path. Like Bradwell, Lockwood also began life as a teacher, when she found herself widowed at the age of twenty-two. Lockwood was a committed suffragist and later credited her friendship with Susan B. Anthony for opening her eyes to expanding educational opportunities for young girls and women. ${ }^{7}$ In 1866, at the age of thirty-six, Lockwood relocated with her daughter to Washington, D.C., where she hoped to pursue a legal career. There, she remarried, and in 1870 she attempted to enroll in the law school at Columbian College, which many years later would become George Washington Law School. Columbian rejected her application, on the ground that "such admission would not be expedient, as it would be likely to distract the attention of the young men."

Undeterred, Lockwood managed to find acceptance in a newly founded law school, the National School of Law, which also would later be subsumed into George Washington Law School. Although she had been accepted, the dean of the law school informed her and the other women who enrolled that they would receive private tutoring but no diploma, because giving women the same treatment as men might undermine the value of the men's diplomas. He kept his word, and when Lockwood completed her studies in May 1873, the school refused to provide her with a diploma, thus, foreclosing her from admission to the District of Columbia Bar. Lockwood fired off an objection to President Ulysses S. Grant, who sat as president ex officio to the school: "I desire to say to you that I have passed through the curriculum of study in this school, and am entitled to, and demand, my diploma." 9 Lockwood received her diploma soon thereafter and gained admission to the District of Columbia bar in 1873.

Lockwood continued to break down barriers. In 1876, her application to join the Supreme Court Bar received a curt denial from Chief Justice Morrison R. Waite, who explained: "By the uniform practice of the Court . . . and by the fair construction of its rules, none but men are permitted to practice before it as attorneys and counselors." ${ }^{10}$ Nevertheless, after Lockwood vigorously pressed her case in Congress, a federal law was amended in 1879 to permit the admission of women to the Supreme Court bar, and in 1880, Lockwood became the first woman ever to argue before the United States Supreme Court. ${ }^{11}$

The difficulties for women in securing legal training on an equal footing with men prompted two female lawyers in Washington, D.C. to take matters into their own hands. Ellen Spencer Mussey (1850-1933) was

7. See Belva A. Lockwood, From the Bag: My Efforts to Become a Lawyer, 19 GreEN BAG 2d 413, 418-19 (2016).

8. Id. at 423 .

9. Id. at $425-26$.

10. Ruth Bader Ginsburg \& Elena Kagan, A Celebration of Justice Ruth Bader Ginsburg: Remarks Commemorating Celebration 55: The Women's Leadership Summit, 32 HARv. J.L. \& Gender 233, 236 (2009).

11. See generally $i d$. 
born in upstate New York, where she received a relatively extensive education in comparison to most women at that time. At the age of nineteen, she moved to Washington, D.C. to take charge of the "ladies' division" of her brother Henry's business college. Two years later, in 1871, she married former Union General Reuben Delavan Mussey, a well-connected Washington lawyer. For several years, Mussey assisted her husband with his legal practice while learning the law herself, even though she had serious reservations about the propriety of women becoming lawyers. When Mussey's husband died in 1892, she wanted to become a lawyer in her own right, but found few options open to her. ${ }^{12}$

Although nearly two decades had passed since Belva Lockwood's admission to the District of Columbia bar in 1873, conditions for women who aspired to become lawyers had not significantly improved. The bar then employed the "diploma privilege," which entitled graduates from the local law schools to become members of the bar, but Mussey had learned the law at her husband's side. Both National and Columbian Law Schools rejected her application, thwarting her attempt to obtain a diploma, and so she instead pursued admission by examination in 1893. Fortuitously, a local judge intervened to waive the written examination requirement, and she passed the bar after an oral examination. ${ }^{13}$

Emma Gillett (1852-1927) spent a frustrating ten years as an underpaid Pennsylvania schoolteacher and then relocated to Washington, D.C. to study law, intrigued by her experience administering her mother's estate. The only law school in the District that accepted female applicants was the historically black Howard University Law School, which Gillett attended, temporarily living with Belva Lockwood as an apprentice in her law office while she studied law at night. Gillett received her diploma in 1882 and then a master's degree in law in 1883, passing the D.C. bar's written examination that year and later becoming the first female notary public in the country. ${ }^{14}$

In 1895, a young woman named Delia Jackson asked Mussey whether she could join her law office as an apprentice. Instead, Mussey told Jackson that if she could find two other women to join her, she would teach the three of them together. Mussey recruited Gillett to join her in this endeavor. Although the timeline is somewhat unclear, it appears that Mussey and Gillett met when they were working together on a proposed Married Women's Property Act for the District of Columbia, which was adopted in 1896 and informally known as the Mussey Act. On February 1,

12. See Mary L. Clark, The Founding of the Washington College of Law: The First Law School Established by Women for Women, 47 AM. U. L. Rev. 613 (1998); Bob Gordon et al., Legal Education Then and Now: Changing Patterns in Legal Training and in the Relationship of Law Schools to the World Around Them, 47 Aм. U. L. Rev. 747 (1998).

13. See Clark, supra note 12 , at 651 n.118. Mussey would later successfully argue ten cases before the United States Supreme Court. Id.

14. See id. at 626 . 
1896, three women met in Mussey's law office as the first students of what would soon become the Washington College of Law. Within a year, Mussey and Gillett had ten students, including one man, although he later dropped out to go to the seminary. ${ }^{15}$

Mussey and Gillett made some attempts to merge their fledgling institution with one of the other local law schools, without success. On April 2, 1898, Mussey and Gillett instead incorporated the Washington College of Law as a degree-granting institution, with Mussey as its founding dean. It was the first law school ever founded by women, the first to have a woman as its dean, and the first to graduate an all-female class, despite being founded as a co-educational institution. Although Mussey and Gillett taught law, eleven of the twelve other instructors at its beginning were male. Notably, the school incorporated as a co-educational institution, and the number of men in the school rose steadily over time until more than half the student body was male in 1914, a proportion that would not change until 1981 at Washington's successor school, American University Law School. ${ }^{16}$ Ignobly, the school adopted a policy of restricting admission to white applicants, even though Gillett was a graduate of the historically black Howard Law School. This policy was explicit in its 1897-1898 catalog, which overtly stated: "[T] he Washington College of Law is the only school in the District, confining its membership to white persons, which admits women as law students." 17 Even in the absence of subsequent similar statements, the law school regrettably reflected the pervasive biases of its times, and did not graduate an African-American student until its successor institution, American University, did so in 1953. ${ }^{18}$

Washington College of Law had six different locations in its first ten years, and it operated only as a part-time night school until 1930. Mussey retired after a stroke in March 1913, soon after she led the Lawyers' Division of the famous suffrage parade held the day before Woodrow Wilson's inauguration. ${ }^{19}$ Gillett succeeded her as dean and remained in that post for ten years. Among its most prominent graduates in the early years was the militant suffragist Alice Paul, the organizer of that parade, who attended school after the passage of the Nineteenth Amendment in 1920 and graduated in 1922. Although female deans continued to lead the

15. See id. at $624-25$.

16. Id. at 654,666 .

17. Id. at 656 (internal quotation marks omitted) (quoting 1898-99 Catalogue of the Washington College of Law, at 5 (on file with the WCL Achieves)).

18. See id. at 656.

19. See Mussey, Ellen Spencer (1850-1936), Encyclopedia.com, https://www.en cyclopedia.com/women/encyclopedias-almanacs-transcripts-and-maps/mussey-el len-spencer-1850-1936 [https://perma.cc/WM7B-5YKQ] (last updated May 1, 2020) ("Mocked, harassed, and shoved by the crowds in attendance, she suffered a stroke brought on by the stress of the event."). 
school until 1947, once the school merged with American University Law School, all subsequent deans were male until 2016. ${ }^{20}$

Mussey and Gillett had founded their own law school in order to have the opportunity to teach law students. In contrast, the first woman ever to teach at an established law school was Lutie A. Lytle (1875-1955), an African-American graduate of Central Tennessee Law School in Nashville. ${ }^{21}$ Indeed, "[i]n the fall of 1898, the Chicago Tribune hailed Lutie A. Lytle of Topeka as the 'only female law instructor in the world.'"22 The daughter of former slaves, Lytle grew up in Topeka, Kansas and became one of the first black women journalists before she decided to apply to law school. She explained: "I read the newspaper exchanges a great deal and became impressed with the knowledge of the fact that my own people especially were the victims of legal ignorance. I resolved to fathom its depths and penetrate its mysteries and intricacies in hopes of being a benefit to my people." 23 Lytle was one of only six students enrolled at Central Tennessee and its only female student. ${ }^{24}$ Her graduation in 1897 as the top student in her class received international attention; "news outlets from as far away as London, England, published news of her graduation, valedictory address, and admission to practice." ${ }^{25}$ Within a year, Lytle left her struggling solo practice to join Central Tennessee's faculty in 1898, where she spent only one year as a professor and law librarian. ${ }^{26}$ She returned to Topeka after that year, married another lawyer in 1901, and later established a practice with her husband in New York City.

Despite the efforts of these early pioneers, opportunities for women as law teachers were virtually nonexistent, even though some doors opened for women as law students. In particular, Arthur Winfield MacLean founded the experimental Portia Law School in Boston as a female-only law school in 1908, and later formally incorporated it in 1918, when it had ninety-eight students. Although always racially integrated from its beginning, the school excluded men until the 1920s. MacLean's wife Bertha taught some courses at the law school, which did not receive

20. See Herma Hill Kay, The Future of Women Law Professors, 77 IowA L. Rev. 5,5 (1991); Former Deans, Am. Univ. Wash. Coll. L., https://www.wcl.american.edu/ impact/history/former-deans/ [https://perma.cc/4BAY-TFC5] (last visited Nov. 24, 2020).

21. See J. Clay Smith, Jr., Black Women Lawyers: 125 Years at the Bar; 100 Years in the Legal Academy, 40 How. L.J. 365, 382 (1997).

22. Taja-Nia Y. Henderson, "I Shall Talk to My Own People": The Intersectional Life and Times of Lutie A. Lytle, 102 Iowa L. Rev. 1983, 1984 (2017) (quoting Personals, Chi. Daily Trib., Nov. 5, 1898, at 6).

23. Id. at 1996.

24. Id. The school later went out of business in the 1920 s after a devastating fire. $I d$. at 1997 n.106.

25. Id. at 2001.

26. See Kansas Historical Society, Lutie Lytle, Kansapedia, https://www.kshs. org/kansapedia/lutie-lytle/12136 [https://perma.cc/KTL4-TWZU] (last updated Jan. 2020). 
accreditation from the American Bar Association until 1969, when it became the New England College of Law. ${ }^{27}$

As the twentieth century dawned, legal education began to undergo a transformation, as new regulatory bodies attempted to standardize and professionalize the teaching of law. Both the American Association of Law Schools (AALS), founded in 1900, and the American Bar Association (ABA), which became the accrediting body for law schools in 1923, played a significant role in this effort, which saw many smaller law schools either merge with others or disappear in the new competitive environment. Law schools actively sought accreditation and imposed new standards for tenuring faculty, replicating the universities that many had joined.

Not surprisingly, women fared poorly in the new world of legal academia. In fact, between 1900 and 1945, only three women had ever held tenured or tenure-track positions at an AALS member law school. ${ }^{28}$ The first woman ever hired by an ABA-accredited law school was Barbara Nachtrieb Armstrong (1890-1976) at the University of California at Berkeley Law School, ${ }^{29}$ who originally held a joint appointment with the law school and the Department of Social Economics in 1921, and later moved to the law school full-time in 1928. Armstrong served on the faculty until her retirement in 1957 and continued to teach courses until 1965, but her greatest achievement outside the law school was as the principal architect of the landmark Social Security Act in the mid-1930s. ${ }^{30}$ Harriet Spiller Daggett (1891-1966) became the first full professor of law at an ABA-accredited school when she received tenure at Louisiana State University in 1931. Nicknamed "Ma" Daggett by her students, a memorial after her death proclaimed, in what presumably was intended to be a compliment: "She was often referred to as the best 'man' on the Faculty." 11

Prior to 1945 , the only other woman with a tenure track appointment at an ABA-approved law school was Margaret Harris Amsler (1908-2002), who joined the faculty at Baylor University Law School in 1941, four years after she had graduated first in her class there. Amsler's students called her "Lady A" during her long tenure at the law school, where she taught until 1972, possibly because "she showed up to class every day wearing a hat and gloves," and although she "had the appearance and demeanor of a traditional Southern lady, ... she clearly had uncommon independence,

27. See Ronald Chester, History's Orphan: Arthur MacLean and the Legal Education of Women, 51 Am. J. Legal Hist. 305 (2011).

28. See Kay, supra note 20, at 6.

29. At this time, the University of California at Berkeley Law School was named the "Boalt Memorial Hall of Law." In 2020, the law school removed the name of John Boalt and officially renamed itself to "align with the university's mission of fostering diversity and equal opportunity on campus." Gretchen Kell, UC Berkeley Removes Racist John Boalt's Name From Law School, Berkeley News (Jan. 30, 2020), https://news.berkeley.edu/2020/01/30/boalt-hall-denamed/[https://per ma.cc/J6B6-5YGR]. This Article will use "Berkeley" throughout.

30. Kay, supra note 20 , at 6 .

31. In Memoriam: Harriet Spiller Daggett, 27 LA. L. Rev. 1, 2 (1966). 
self-confidence, and resolve." ${ }^{32}$ Berkeley's first female dean, Herma Hill Kay, later recalled that her inspiration to go to law school came from Amsler, who was the mother of one of her college classmates. ${ }^{33}$ After World War II, Jeanette Ozanne Smith joined the ranks of female law professors when she became an assistant professor of law at the University of Miami Law School in 1949. ${ }^{34}$

The most notable of these early women law professors was the redoubtable Soia Mentschikoff (1915-1984). Born in Moscow, Russia, Mentschikoff emigrated to New York City with her parents as a child. After obtaining a degree from Hunter College in 1930, Mentschikoff attended Columbia Law School, where she became a research assistant to one of the best-known law professors in the country, Karl Llewellyn (1893-1962). Although Mentschikoff graduated in 1937, she and Llewellyn maintained a productive working partnership that became a romantic relationship over time, and she became Llewellyn's third wife in 1946. ${ }^{35}$ At that time, Mentschikoff was one of the first women ever to make partner at a major New York law firm. ${ }^{36}$

In 1947, Mentschikoff made national news when Harvard Law School hired her as a visiting professor, the first woman ever to join its faculty, at a time when its student body was male only. Dean Erwin Griswold visited her at her law firm and personally recruited her to join the faculty to teach sales and commercial law as a visiting professor. ${ }^{37}$ "The media made much hoopla about the fact that an attractive woman in her early thirties would be occupying the chair once held by Samuel Williston. Reporters were struck by Mentschikoff's height as well as her deep voice, which was likened to that of Marlene Dietrich and Lauren Bacall."38 The Harvard Alumni Bulletin explained: "[I]t is her specialized professional competence rather than her sex which will entitle her to sit in the chair once ornamented by the great Williston." 39 Karl Llewellyn joined her at Harvard the following year, ultimately creating a conundrum for the law

32. Local Woman Born 110 Years Ago Led the Way for Women Lawyers in Texas, KWTX, https://www.kwtx.com/content/news/Local-woman-born-110-years-agoled-the-way-for-women-lawyers-in-Texas-485613061.html [permalink unavailable] (last updated June 14, 2018, 6:38 PM).

33. See Herma Hill Kay, First Women: Herma Hill Kay, Ms. JD (Feb. 20, 2007), https://ms-jd.org/blog/article/first-women-herma-hill-kay [https://perma.cc/ 3YK3-ELFC].

34. See Kay, supra note 20, at 9.

35. See James J. Connolly et al., Alcoholism and Angst in the Life and Work of Karl Llewellyn, 24 Oнiо N.U. L. Rev. 43, 99-100 (1998).

36. See Hannah Brenner \& Renee Newman Knake, Shortlisted, 24 UCLA WoMEN's L.J. 67, 81 (2017).

37. See Mary Elizabeth Basile, False Starts: Harvard Law School's Efforts Toward Integrating Women into the Faculty, 1928-1981, 28 HARv. J.L. \& GENDER 143, 149 (2005).

38. Id. (citation omitted) (footnotes omitted).

39. Id. (quoting Non Sub Homine, Harv. Alumni Bull., Nov. 23, 1946, at $212,213)$. 
school, which had an anti-nepotism policy that precluded hiring spouses in the same department. Although the faculty had a strong preference for Mentschikoff over Llewellyn as a permanent hire, it did not pursue her further because it was clear that the two of them would want to teach at the same school. The couple's attempts to join the Columbia law faculty also foundered on its anti-nepotism policy. ${ }^{40}$

In 1951, Mentschikoff and Llewellyn both joined the faculty at the University of Chicago Law School. Under Chicago Law's interpretation of its anti-nepotism rules, Llewellyn joined as a full professor, but Mentschikoff became an untenured "professional lecturer," a title she would hold until her husband's death in 1962. Unsurprisingly, she was paid less than her husband, despite her exceptional scholarly contributions at Harvard. ${ }^{41}$ She left Chicago Law in 1974, became the first woman to head the AALS, and later served as dean of the University of Miami Law School until her retirement in $1982 .{ }^{42}$

Despite having experienced open discrimination on the basis of sex with respect to her rank and salary at Chicago Law, Mentschikoff generally showed little sympathy to other women struggling to achieve equality in the male-dominated field of law. ${ }^{43}$ She denied that she had ever experienced discrimination as a woman and once remarked "that if she were the hiring partner at a large firm she would not consider lawyers who happened to be potential mothers." ${ }^{4}$ Her view was that "women who were determined to make it could do so and that it was their own fault if they did not." 45

Throughout the first half of the twentieth century, the status of women within legal academia was that of an almost invisible minority. ${ }^{46}$ In addition to the handful of tenure-track appointments, a few women managed to find teaching jobs with titles such as "research associate," "lecturer in law," or "visiting assistant professor," with no job security. On occasion, "[s] ome of these women ultimately were admitted to the regular academic ranks, often after they had devoted their full-time efforts to the law school for many years." ${ }^{47}$ For example, one of the few black women known to

40. See Robert Whitman, Soia Mentschikoff and Karl Llewellyn: Moving Together to the University of Chicago Law School, 24 Conn. L. Rev. 1119, 1991-92 (1992).

41. See Brenner \& Knake, supra note 36, at 101.

42. See Basile, supra note 37 , at 151 .

43. See Renee Knake Jefferson \& Hannah Brenner Johnson, Shortlisted: Women In The Shadows Of The Supreme Court 146-47 (NYU Press 2020).

44. Terry Carter, Women Face Hurdles as Professors; The Influx of Female Lawyers into the Legal Profession is Undergoing Severe Scrutiny-Especially in Law Schools, 11 NAT'L L.J. 1 (1998).

45. Cynthia Grant Bowman, Women in the Legal Profession From the 1920s to the 1970s: What Can We Learn From Their Experience About Law and Social Change?, 61 Me. L. Rev. 1, 5 (2009).

46. See generally Kay, supra note 20. Herma Hill Kay identified thirteen fulltime tenure/tenure-track female faculty between 1949 and 1959. Id. at 8 .

47. Id. at 9 . 
have held a teaching position in a law school prior to 1950 was Ollie May Cooper, who graduated from Howard Law School in 1921, magna cum laude, and then spent forty years as the secretary to the dean, while practicing law at night. Cooper, the first black woman attorney known to have opened her own law firm, began teaching courses in 1925, "without pay and recognition." Thurgood Marshall, a 1933 graduate of Howard Law, referred to her as the "real Dean." 48

The only area in law schools where women predominated relative to their numbers was in law libraries.

In 1950, about half (or 54) of the head librarians of the nation's law schools were women. Like their male librarian counterparts, virtually none of these women taught any courses other than legal bibliography or legal research and writing, despite the fact that about half had J.D. degrees and several held academic ranks of assistant professor or higher. ${ }^{49}$

As Ruth Bader Ginsburg put it bluntly in 1982: "In 1950, in all ABAaccredited law schools, 5 women were engaged as full-time tenure-track teachers. Literally, women who worked as law teachers could be counted on the fingers of one hand." 50

\section{II. “Taking the Place of a Man": 1950-1969}

Although the American bar was overwhelmingly male in 1950, there had been a measurable uptick in the number of women who entered the legal profession. Driven in part by necessity during World War II, many law schools had offset the shortfall in male applicants due to military service by admitting female students. In 1940 , there were about 4,500 women lawyers in the country, comprising $2.4 \%$ of the total. In 1950 , that number had increased by nearly 2,000 , to about 6,350 , still a very small minority of the practicing bar. The number of women entering law school would increase gradually over the next two decades despite overt barriers to their

48. J. Clay Smith, Jr., Emancipation: The Making of the Black Lawyer, 1844-1944 86 n.228 (Univ. of Pa. Press 1993); J. Clay Smith, Jr, Inaugural Presentation of the Ollie Mae Cooper Award, 23 Howard L.J. 369, 370 (1980). The other African-American woman known to have taught law school courses at this time was $\mathrm{H}$. Elsie Austin (1908-2004), who served on the faculty of the Robert H. Terrell Law School, which operated from 1931-1950. See J. Clay Smith Jr., ED., Rebels in Law: Voices in History of Black Women Lawyers 302 (Univ. of Mich. Press 2000).

49. Donna Fossum, Women Law Professors, 5 Am. B. Found. Res. J. 903, 903 (1980) (footnote omitted). Fossum noted that "women have always been found in greater than expected numbers in the 'backroom' areas of law. In the practicing sector of the legal profession this has meant that women have clustered in areas involving the least client contact, such as government work, trusts and estates, and tax." Id. at 904 .

50. Ruth Bader Ginsburg, Women's Work: The Place of Women in Law Schools, 32 J. Legal Educ. 272, 272 (1982) (footnote omitted). "When the women numbered 5 , the male count was over 1200.” Id. 
entry, as most law schools had secret quota systems to limit the number of female students in each class. ${ }^{51}$

Women who managed to gain acceptance to law school during this time faced daunting challenges in the male bastion of legal academia. Most law schools had no women on their faculties. Indeed, only eight women would secure tenure-track teaching positions during the 1950s. Among them were Ellen Ash Peters (1930-), the first woman on the Yale Law faculty, who would later become the first woman appointed to the Connecticut Supreme Court, and Dorothy Wright Nelson (1928-), the first woman on the faculty of the University of Southern California Law School, who later became its dean and then a judge on the United States Court of Appeals for the Ninth Circuit. ${ }^{52}$ In addition, the founding dean of Seton Hall Law School, Miriam Theresa Rooney (1897-1981), became the first woman to serve as dean of an ABA-approved law school when she was appointed in 1951.53 Any complete list of pioneering women law professors prior to 1960 would also include many law librarians who received the title of "professor of law." 54

Although the number of women who attended law school in the ' $50 \mathrm{~s}$ and '60s was relatively small, that group would generate the first sizeable cohort of female law professors. Most of them would have no female role models in the classroom, and many experienced open hostility from classmates and faculty. For many of those women, their law school experience as members of an unwelcome and often besieged minority shaped their future careers in academia.

The iconic story of the reaction to women law students in the 1950s had often been recounted by Ruth Bader Ginsburg (1933-2020) and was recently immortalized in the 2018 film, On the Basis of Sex. Dean Erwin Griswold (1904-1994) invited the nine women in the first-year class at Harvard Law to his home. Seating them in a semicircle before him, he then asked each woman to explain why she was at Harvard taking the place of a man. In the film, as in life, Ginsburg stated: "My husband, Marty, is in the second-year class. I'm at Harvard to learn about his work. So that I might be a more patient and understanding wife." 55

51. Cynthia Fuchs Epstein, Women in Law 50 (1981).

52. See Lisa A. Kloppenberg, CLEPR's 40th Anniversary: Papers and Speeches From the AALS-ABA-CLEA Celebration of CLEPR: CLEPR Anniversary Remarks Regarding Judge Dorothy Wright Nelson, 16 Clinical L. Rev. 29 (2009).

53. See Kay, supra note 20, at 8 n.19. Kay explained that Rooney had begun her career as the law librarian at Catholic University of America School of Law in 1942 but did not become a "full-time or full-fledged law professor" until she became the founding dean of Seton Hall. Id.

54. See generally D. Michael Risinger, Female Law Librarians as Pioneer Women Law Professors: A (Belated) Response to Dean Kay, with Some Suggested Additions to Her Canonical List., 112 LAw Libr. J. (forthcoming 2021), http://dx.doi.org/10.2139/ ssrn.3624525 [https://perma.cc/HQM3-GGXK].

55. Jill Lepore, Ruth Bader Ginsburg's Unlikely Path to the Supreme Court, New YORKER (Oct. 1, 2018) (internal quotation marks omitted), https://www.newyork 
In later years, both Ginsburg and Griswold suggested that this incident was more complicated than an overt attempt to intimidate women law students. In a 2013 interview, for instance, Ginsburg said:

Years later, Griswold told me he didn't ask the question to be unkind. He said there were still doubting Thomases on the faculty who thought it was unwise to admit women. So the dean wanted to be armed with stories from the women themselves, about what use they would make of their legal education, so that he could satisfy his dubious colleagues. ${ }^{56}$

For his part, Griswold seemed mortally offended that anyone could have misunderstood his pure intentions in questioning women this way. He prided himself on having overseen the opening of Harvard Law School's doors to women in 1950 and complained that he did not seem to get enough credit for that achievement from subsequent generations of female law students, whose ungrateful reaction was, "Well, why didn't you do it sooner?"57 By his own account, however, he could have allowed women into Harvard earlier than 1950 but chose not to do so because he wanted to preserve all seats for men returning from World War II. As he admitted: "[A]lthough I knew we could get the Harvard Corporation to let us admit women, I deliberately postponed it until 1948 because I didn't think it was decent to keep anybody who had been in service from getting a chance for a Harvard education." ${ }^{8}$ In his view, "there were lots of firstclass law schools [women] could get into and lots of them did." 59 One wonders whether a similar notion of fairness would have applied to excluding Jackie Robinson from Major League Baseball as white baseball players returned from the war.

Nevertheless, Yale's law dean assured Griswold "that the admission of women would not be a shattering experience." 60 Griswold recalled that he had "maneuvered the admission of women" over some initial opposition by about one-third of the law faculty and ultimately was able to shepherd it through with only "four negative votes of whom [Edward Henry] Bull Warren was one-he said he would have to revise all his notes, which

er.com/magazine/2018/10/08/ruth-bader-ginsburgs-unlikely-path-to-the-supreme-court [https://perma.cc/8R88-SU67].

56. At the U.S. Supreme Court: A Conversation with Justice Ruth Bader Ginsburg, Stan. Law. (Nov. 11, 2013), https://law.stanford.edu/stanford-lawyer/articles/le gal-matters/ [https://perma.cc/P72J-7ZXQ].

57. Interview by Victoria L. Radd, Esquire, with Erwin N. Griswold, Esquire, Hist. Soc'y D.C. Cir., in Washington, D.C. at 16 (Jan. 13, 1992).

58. Id. at 15 .

59. Id.

60. Erwin N. Griswold, Letters to Harvard's Griswold: To a Fellow Dean, a Wise and Generous Friend, 18 U. Miami L. Rev. 8, 9 (1963). 
some people thought was a good idea." ${ }^{61}$ As Harvard Law School announced its new policy, Griswold tamped down expectations of great change:

[I]t does not seem to me that this particular development is either very important or very significant. Most of us have seen women in our lives from time to time during our lives and have managed to survive the shock. . . . There seems to be no likelihood that we will have a very large proportion of women among our students. ... . As of today, I doubt if this change alone will require any of our faculty members to revise many of their lectures. ${ }^{62}$

Viewing himself as a champion of women, Griswold found himself on the defensive in later years when women recounted their experiences with him at Harvard. In his memoir, he asserted that questioning women at these dinners "was intended 'to encourage the women to make full use of their legal training, in practice or in service, of varying kinds, to the public." 63 When President Bill Clinton nominated Ginsburg to become an Associate Justice of the Supreme Court, she recounted some of her experiences at Harvard, and Griswold testily defended himself in the press. He now claimed that his practice of asking female students to justify their presence at Harvard "was playing devil's advocate and trying to get justification for his own beliefs that the women intended to become lawyers." 64 He said that Ginsburg was "dead wrong" about his question, adding: "I think she completely misunderstood it and should have known better." 65

It was not only Ginsburg who had found Griswold's annual interrogation of the first-year women law students to be uncomfortable, if not openly hostile. Pat Schroeder (1940-), who would later serve in the United States House of Representatives, recalled her experience as a firstyear law student in 1961:

[Griswold] had all the women over to his house the first week, and he put us in a circle and said, "I want to know why you came here." His spin was: We let you in equally, but I don't think any of you are going to use this [law degree]. So, we count how many

61. Interview with Griswold, supra note 57, at 16 . The famously irascible Warren died in 1945, and so Griswold's memory may have been somewhat faulty about the timing of his remarks.

62. Erwin N. Griswold, Developments at the Law School, Harv. L. ScH. Y.B. 10 (1950).

63. Basile, supra note 37, at 154 n.100 (quoting Erwin N. Griswold, Ould Fields, New Corne: The Personal Memoirs of a Twentieth Century Lawyer 173-74 (1992)).

64. Ira E. Stoll, Ginsburg Blasts Harvard Law: Past, Present Deans Defend School, Harv. Crimson (July 23, 1993), https://www.thecrimson.com/article/1993/7/23/ ginsburg-blasts-harvard-law-pin-testimony/ [https://perma.cc/5CXS-K264].

65. Id. 
of you there are, and we let in that many more men. I don't know what they thought - that we were going to hang the degree over the changing table or something? . . . Here was this very bright man who understood racism, but did not understand at all that he was being very sexist saying such a thing. Well, he went around and asked each of us why we came [to Harvard]. Of course, everyone is shaking in their chair because this is the dean-except for this wonderful young woman from California. She looks him straight in the eye and says, "Well, I am only here because I could not get in at Yale." He went ballistic. ${ }^{66}$

“'It broke all the tension,' [said] Schroeder, 'but I thought, "Why in the world are we playing this game?" It was astounding to me." 67 Similarly, Judge Jane Roth of the United States Court of Appeals for the Third Circuit, a 1965 graduate of Harvard Law, quoted Griswold as telling the twenty-five women in her class at his annual dinner: "I hope that you realize that each one of you has taken the place of a young man who would have a future in law." 68 Roth recalled: "In the fall of 1962, you did not [respond], you just smiled and you didn't argue with him. No one said anything." 69

In addition to this peculiar form of annual interrogation of female students at Harvard Law, the law school classroom of the 1950s and 1960s could be equally daunting for women. The most notorious form of hazing of female law students during the early years was a phenomenon known as "Ladies' Day." There is a record of it occurring as early as 1932 at Fordham Law School, known as "a day on which some professors would call on women, who otherwise were expected to be silent in their classes." 70 The tradition took hold quickly at Harvard Law School once women were admitted as law students and later found its way to other law schools. Although only a handful of faculty seem to have participated, their routines were well-known to the women students.

Harvard professors James Casner (1907-1990) and Barton Leach (1900-1971) were the two most infamous practitioners of this putative tradition. Leach "sat in the audience and asked questions in a 'humorous' tone of the women who were exhibited on the podium rather like per-

66. Lee Sigelman, Pat Schroeder Strikes Back at Harvard and Congress, Monkey CAGE (Feb. 22, 2008) (second and third alterations in original), http://the monkeycage.org/2008/02/post_58/ [https://perma.cc/E6WW-6GDT]; see also Margie Kelley, When I'm '64, HARv. L. TodAY (July 1, 2003), https://today.law. harvard.edu/feature/im-64/ [https://perma.cc/G23Z-3C7J]. The woman who talked back was Ann Cronkhite Goldblatt, later a prominent bioethicist. Id.

67. Kelley, supra note 66.

68. O Pioneers! Pat Ciarrocchi Interviews Judges Jane R. Roth, Helen S. Balick and Roxana C. Arsht, Del. LAw., Fall 2001, at 1, 28, 30 (internal quotation marks omitted).

69. Id.

70. Elizabeth B. Cooper, 100 Years of Women at Fordham: A Foreword and Reflection, 87 Fordham L. Rev. Online 39, 39 (2019). 
forming bears."71 James Casner conducted a similar exercise, recalled by a former student who was a first-year law student in 1965:

Our turn at Ladies' Day began when, on a Friday, Professor Casner announced that the following Monday would be "Ladies' Day" and the topic would be marital gifts. We five women prepared furiously all weekend. As Pam says, "We were so prepared; but we weren't prepared for what happened." As the one woman seated in the front row, I was called on first. Leaning over, Casner said to me, "Miss Mullarkey, if you were engaged-and I notice you're not"- he paused for laughter- "would you have to return the ring if you broke the engagement?" That was the sole question asked of me in a full-year property class. Pam was asked a question about premarital property settlements, and the other questions were similar. ${ }^{72}$

She recalled this activity as "a very public silencing of women, . . . a meanspirited game that marginalized women and reinforced the view that women in the law were not to be taken seriously." ${ }^{3}$ Like many women during this time period, she did not protest to the professor, although she recalled writing to the student newspaper, "saying that I doubted the practice would have been tolerated if it had been directed at any other identifiable group." ${ }^{4}$ Another woman recalled Casner's quizzing about divorce as "an entertainment, a show put on at our expense." 75

Law professors who engaged in Ladies' Day harassment often intentionally reserved class material that could be seen as embarrassing to the handful of female students, "topics that were considered trivial, of special interest to women, or sexually embarrassing, such as an engagement ring as a marital gift, rights to deceased husbands' property, fraudulent sale of underwear-or rape." ${ }^{\prime 6}$ One professor chose to hold Ladies' Day on February 14, known among the students as the "Valentine's Day massacre," when he would do "all the embarrassing and difficult to discuss problems." 77 The atmosphere in class could be "raucous, as male students "hooted and laughed and sometimes stomped their feet, thinking it was marvelous fun.' Several women likened the experience to performing like caged animals."78 At Columbia Law School, one professor began Ladies' Day by announcing: "Will all the little virgins please come to the front of

71. EPstein, supra note 51, at 66.

72. Mary J. Mullarkey, Two Harvard Women: 1965 to Today, 27 Harv. Women's L.J. 367, 370 (2004) (footnote omitted).

73. Id. at $370-71$.

74. Id. at 371 .

75. Epstein, supra note 51, at 66.

76. Jeannie Suk Gersen, The Socratic Method in the Age of Trauma, 130 HARv. L. Rev. 2320, 2329 (2017).

77. Epstein, supra note 51, at 66 (first internal quotation marks omitted).

78. Gersen, supra note 76, at 2329 (footnote omitted) (quoting Judith Richard Hope, Pinstripes \& Pearls: The Women of the Harvard Law Class of '64 
the room."79 A student archly commented later: "Of course the women didn't know whether to go or not." 80

This particular form of harassment was not limited to Harvard. Joyce Hens Green (1928-), later a United States District Judge for the District of Columbia, reported her experience as a law student at the University of Maryland in the late 1940s:

There was a professor at Maryland who always called upon one of the women in class to recite page 100 of the criminal law book. Page 100 dealt with a particularly salacious situation involving a rapist, graphic detail about that person's activities and the defense that he raised; I knew before I went to the first class in law school that when page 100 was reached, one of the three of us would be chosen to stand and recite. And if she was able to get through that session without fainting, without blushing or stammering, without embarrassing herself, that professor would never call upon her again. That's exactly what happened. Guess who was the chosen one my year? I managed to get through it without doing anything horrible and I was thereafter ignored by our learned professor for the rest of the course. ${ }^{81}$

Her District Court colleague June Green (1914-2001) also recalled unequal treatment as a student at Washington College of Law in the early 1940s:

[A]ll the women warned me about . . . the professor who was teaching Constitutional Law. If you had a question, don't go to his chambers, because he was really very, very rough. Aggressive. Trying to appall the gals. It got to be a joke, really. . . . The other one was worse, in a different way. He was incensed that he had women in his class. . . . He had a wonderful knack of looking through me, over me, not ever seeing me. It really was quite an interesting experience, to think that you were non-existent. ${ }^{82}$

Even at law schools that did not formalize their hazing of female students, the harassment could still be pervasive. At Georgetown, Marna Tucker (1941-) remembered "standing in all of those classes, being embarrassed during the sex cases when they would always, of course, call on the women. We didn't have 'women's day' like they did at Harvard, but it

Who Forged an Old-Girl Network and Paved the Way for Future Generations $99(2003))$.

79. Epstein, supra note 51, at 66 (internal quotation marks omitted).

80. Id. at 66 .

81. Interview by Jennifer M. Porter with Judge Joyce Hens Green, Historical Soc'y of the D.C. Circuit at 45-46 (Sept. 16, 1999).

82. Interview by Sally Gere with Judge June Green, Historical Soc'y of the D.C. Circuit at 50-51 (Sept. 7, 1997). 
was very, very difficult."83 Janet Riley (1915-2008) had the same experience at Loyola University New Orleans College of Law, when she knew that the next day's class assignment was "one of these very explicit cases about sex," that would be saved for "the girl in the class." ${ }^{4}$ Even though she was accidentally late for class after staying up late to prepare, the professor said: "We waited for you," to giggling from the entire class. 85 "I told him all about it as explicitly as necessary." ${ }^{66}$ Wendy Williams (1944-), who would later argue sex discrimination cases before the Supreme Court, fumed about the professor at Boalt Hall who

said to one of the women, "I see you're sitting up near the front of the class." Then he says to another woman, "I see you're sitting up in back." "Well," he says, "some women like it in the front and some like it in the back." The guys all laughed. I couldn't believe it. ${ }^{87}$

Some professors attempted to justify this behavior as benign.

One female 1963 graduate told Judith Richards Hope that a professor who refused to call on women except on ladies' days probably did so out of a paternalistic feeling that he shouldn't do to the women what he was able to do to the men: "[P] ush them to the wall with questions." Another recalled that the professor explained in class that "it was unchivalrous to call on a lady without advance notice." 88

At St. Mary's Law School in Texas, where Ladies' Day persisted into the 1980s, the law professor who was "the most notorious practitioner of this game, would attempt to make amends for having so much fun at students' expense by hosting a cocktail party in the spring and inviting only the women in his classes, at which time, he and his wife were most gracious hosts." 89

Oddly, at least one woman later recalled this type of treatment with fondness. Dorothy Wright Nelson noted that she and a classmate anticipated this behavior and did not object, explaining:

83. Interview by Mary L. Clark with Marna S. Tucker, Am. Bar Ass'n at 9 (Sept. 8, 2006).

84. Myriam Miedzian \& Alisa Malinovich, Generations: A Century of Women Speak About Their Lives 402 (Atlantic Monthly, 1st ed. 1997).

85. Id.

86. Id. at 403 .

87. Interview by Jennifer Lyman with Wendy W. Williams, Am. Bar Ass'n at 24 (Mar. 20, 2006).

88. Gersen, supra note 76, at 2329 (alteration in original) (footnote omitted) (first quoting Hope, supra note 78, at 97; then quoting Hope, supra note 78, at 98).

89. Barbara Hanson Nellermoe, 50 Years of Excellence: A History of the St. Mary's Law Journal, 50 ST. Mary's L.J. 1, 24 n.123 (2019). 
Most women would be outraged, but Ann and I knew that we would never be called upon unless he announced that tomorrow was Women's Day. So when he would announce it, then we would go home and prepare like crazy and we'd be super-prepared. We just loved it. But I never ever felt discriminated against in that class. ${ }^{90}$

The alternative response of some male faculty to their presence in class was to call on them more than they called on the men. Herma Hill Kay was a law student at Chicago in the mid-1950s, when Sonia Mentschikoff and Karl Llewellyn were on the faculty. When she failed one of Llewellyn's exams, he called her into his office and informed her: "It's very difficult for a woman to succeed in law. You can't take Miss Mentschikoff as an example. Miss Mentschikoff is exceptional."91 On the other hand, another professor, Walter Blum, announced at the beginning of his tax class that

Miss Mentschikoff had made it clear to him that he needed to treat women the same way he treated men because this was a professional school. Therefore he had decided that he was going to call on a man and he was going to call on a woman, then he was going to call on a man then he was going to call on a woman. ${ }^{92}$

Kay recalled that this was "just fine except that I was the only woman [laughs], so I learned more about corporate tax then I ever wanted to know."93 Kamilla Mildred Mazanec (1935-2017) also had ample opportunity to shine in one first-year class at the University of Missouri at Kansas City School of Law, when "a professor called upon her to recite in 31 of the course's first 32 meetings, espousing the opinion that women in the profession were competing with men who needed the jobs to support their families." 94

For other women, the alternative to Ladies' Day badgering was being ignored completely in the classroom. One Harvard law student recalled that her professor claimed that he had called on everyone in the class that year and seemed perplexed when she pointed out that he had never called on any of the women. ${ }^{95}$ Indeed, "[e]ven the most liberal [men] rarely called on women, and, when they did, hurried to get on to a man they

90. Interview by Angela E. Oh with Dorothy W. Nelson, Am. Bar Ass'n at 15 (May 24, 2006).

91. Interview by Germaine LaBerge with Herma Hill Kay, U.C. Berkeley, Regional Oral Hist. Off. at 27 (June 24, 2003) (internal quotation marks omitted).

92. Id.

93. Id. (alteration in original).

94. Kentucky Bar Association, Kamilla Mildred Mazanec Obituary, Bench \& B. MAG., Sept.-Oct. 2017, at 1, 53.

95. Epstein, supra note 51, at 65. 
could harass without fear of provoking overt (i.e. feminine) collapse." ${ }^{96}$ Phyllis Kravitch (1920-2017), later a judge on the United States Court of Appeals for the Eleventh Circuit, attended law school at the University of Pennsylvania in the 1940s, and although she thought the handful of women there had generally been treated fairly, she noted that one professor took the position that he would never call on a woman:

And one time, after two or three men that were called on didn't give the right answer, he said, "Is anyone else prepared to recite?" And I raised my hand and I said, "Professor Chadwick, I would like to." And he said, "Because no one is prepared, I'll discuss the case myself." 97

Hostility to the presence of women law students manifested itself in countless other ways during these early years. Pat Schroeder recalled some men refusing to sit near women in class or in the cafeteria, seeking to avoid what she sardonically referred to as "estrogen contamination."98 Like many of her peers at other schools, she deeply resented being questioned about "taking the place of a man." ${ }^{99}$ Other women found themselves at the receiving end of asked a somewhat less confrontational question: "[W] hat is a nice girl like you doing in a place like this?" 100 Marna Tucker (1941-), later to become the first female president of the District of Columbia Bar, remembered:

[T] here was a guy who came up to me and said something about, "Are you here to get a husband?" And I said, "Why would I come to law school to get a husband; I mean, isn't that an awful lot of work to get a husband? Wouldn't it be easier to be a stewardess or something like that?"101

By the '60s, during the Vietnam era, women would also be accused of sending men to their deaths in battle by depriving them of a seat that would have granted a student deferment. ${ }^{102}$

Various aspects of law student life were off limits to women during this time. Ginsburg testified at her confirmation hearings that she had been "shut out of Lamont library, which was closed to women when she was a student at Harvard Law School in 1956 to 1958. She said women guests were not invited to the Harvard Law Review banquet, and that wo-

96. $I d$. at 66 .

97. Interview by Anne Emanuel with Phyllis A. Kravitch, Am. Bar Ass'n, Atlanta, Ga., at 4 (July 17, 2013).

98. Deborah L. Rhode, Midcourse Corrections: Women in Legal Education, $53 \mathrm{~J}$. LegAl EDUC. 475, 479 (2003) (internal quotation marks omitted), quoted in Hope, supra note 78 , at $81,87-88$.

99. Kelley, supra note 66.

100. EPSTEIn, supra note 51, at 63 (internal quotation marks omitted).

101. Interview with Tucker, supra note 83, at 5 .

102. Epstein, supra note 51, at 63. 
men were not given space in the Law School dormitories."103 Barbara Babcock (1938-2020), who started at Yale Law School in 1960 as one of 13 women in a class of 175 , commented:

[E]ven though we were the victims of the most overt sex discrimination you could imagine, we really didn't know it on some level. Things like women couldn't live in the ... nice suites in the law school that were connected with the law school and you didn't even have to go outside in the rain or snow and they had fireplaces, but women couldn't stay there. ${ }^{104}$

Unsurprisingly, the inevitable issue of restrooms that seems to accompany every struggle for civil rights emerged as women entered the law schools. At Harvard, for example, the evaluation of the cost of admitting women as students included one major expense: the creation of a woman's bathroom in the basement of Austin Hall. Ginsburg recalled:

Back then, Harvard had two classroom buildings, Austin and Langdell. Only Austin had a women's bathroom. So if you were taking a class, or worse, an exam, in Langdell, you had to make a mad dash if you needed to use the bathroom. Yet, amazing from today's perspective, we never complained about it. It was just the way things were. ${ }^{105}$

Marna Tucker had a similar recollection from her days as a Georgetown law student in the early 1960s, when she was 1 of 9 women in a class of 180 . "Not only was the ladies room in the basement, it was totally neglected[,]" she reported. ${ }^{106}$ "People forgot that it was there and so it wasn't cleaned; it never had supplies. It was just not a very pleasant place." 107

Other indignities made women feel unwelcome in law school. Barbara Babcock, later to become the first female tenured faculty member at Stanford Law, reported that she had been passed over to become an editor of the law review because "they had a woman who had been an officer a couple of years previous and she hadn't worked out so they weren't ready to try another woman."108 Sylvia Law (1942-) remembered a law professor who told her it was not good for the school for the "girls" to take a place on the Dean's List since the school needed those on the Dean's List

103. Stoll, supra note 64.

104. Interview by LaDoris Cordell with Barbara A. Babcock, Am. Bar Ass'n at 14 (Jan. 18, 2006).

105. At the U.S. Supreme Court, supra note 56; see also Rhode, supra note 98, at 479. It was described by one person as a "hastily converted basement janitor's closet." Rhode, supra note 98, at 479.

106. Interview with Tucker, supra note 83.

107. Id.

108. Interview with Babcock, supra note 104. 
to "bring honor, prestige, and money to NYU."109 Mildred Lillie (1915-2002) was called "mister" by her criminal law professor at Berkeley, although she persevered and later served as a judge in the California state court system for more than fifty years. ${ }^{110}$

Male students sometimes undermined their female colleagues who received high grades by claiming favoritism, asserting "oh, so-and-so likes girls." 111

Women in law school during these years also found themselves isolated from male law students. For example, in the all-male dormitories on several campuses, male students typically formed study groups and did not allow female students to join. Brooklyn Law School even physically segregated women in the classroom. ${ }^{112}$

A graduate of the University of Texas Law School in the 1960s remembered how the law school yearbook once featured "the Texas Law Review members (all male) were pictured looking at 'girlie' magazines (those magazines containing pictures of nude or scantily-clad women). Another year, there was a cartoon of a woman with large and pointy breasts; the woman said, 'A couple of points I want to bring out!'"113 Mary Schroeder (1940-), later to serve on the United States Court of Appeals for the Sixth Circuit, commented that the faculty at the University of Chicago were aware of the toxic environment for women: "They made it that way. They promoted that kind of an atmosphere. . . . I think you become hardened and much more determined when you have experiences like that."114

Even the structure of law school social life could operate to marginalize women law students. As Barbara Black (1933-) later pointed out:

[T] he era of "The Law Wives," an organization of spouses, female, of students, male, who met for tea, planned bake sales, bridge parties, picnics, babysitting pool, fashion shows, and volunteer work for legal aid societies, and invited speakers, one of whom "addressed himself to "the importance of a well informed law wife (educated but not equal)'[!]”; although there were some

109. Sylvia A. Law, The Voices of Women: A Symposium on Women in Legal Education: Good Intentions Are Not Enough: An Agenda on Gender for Law School Deans, 77 IowA L. Rev. 79, 80 (1991).

110. JeFFERSON \& Johnson, supra note 43, at 56, 59.

111. Epstein, supra note 51, at 64.

112. Janet Taber et al., Gender, Legal Education, and the Legal Profession: An Empirical Study of Stanford Law Students and Graduates, 40 Stan. L. REv. 1209, 1210 (1988) (footnote omitted).

113. Allison L. Bowers, Women at the University of Texas School of Law: A Call for Action, 9 Tex. J. Women \& L. 117, 122 n.20 (2000) (citing Univ. OF Tx. Sch. OF Law, The Peregrinus 198 (1962)).

114. Interview by Patricia Lee Refo with Mary M. Schroeder, Am. Bar Ass'n at 36 (Aug. 30, 2006). 
Law Husbands around, it would not have occurred to anyone that this organization ought to be called The Law Spouses (far less Spouses and Significant Others, a category certainly in existence if not much in evidence), nor would the husbands likely have participated. ${ }^{115}$

Of course, the difficulties were even more pronounced for the tiny group of African-American women who entered law school during this period. Patricia King (1942-), who would later become the first AfricanAmerican law professor at Georgetown, was one of three black women in a class of 500 students when she transferred to Harvard Law in 1966. "The women were always objects of curiosity[,]" she reported. ${ }^{116}$

Male students noticed what we wore, how we sat and made comments about our physical characteristics. Women could not be members of Lincoln's Inn, an eating society. And my moot court advisor (a [sic] second year student) said the moot court clubs didn't like to admit women because they cried!!117

But in addition, King recalled that she "was aware of the differences between white women and black women. I joined a black woman's consciousness-raising group." 118

In later years, some women who had endured the hostile environment of law school in silence would question why they had not rebelled against these conditions. Sheila Birnbaum (1942-), who attended NYU in the early 1960s, explained that even though the criminal law professor who called only on women for rape cases was "quite offensive," she thought that:

[W] e were fairly passive because our consciousness hadn't been raised. We were glad to be there, and we weren't the group that made waves. Those women came after us. We just wanted to get the doors open and get through them. So, I think for most of us, at least for myself-you conformed. You went along with authority. You played the game. ${ }^{119}$

Barbara Black raised the same issue many years after her law school experience, when she was serving as the first female dean of Columbia Law School:

115. Barbara Aronstein Black, In Commemoration: Something to Remember, Something to Celebrate: Women at Columbia Law School, 102 Colum. L. Rev. 1451, 1458-59 (2002) (second alteration in original) (footnotes omitted) (quoting Law Wives Program Includes Many Events, Colum. L. Sch. News, Nov. 2, 1964, at 3).

116. Interview by Naomi Mezey with Patricia A. King, Am. Bar Ass'n, in Washington, D.C. at 6 (May 22, 2007).

117. Id.

118. $I d$.

119. Interview by Linda Hayman with Sheila L. Birnbaum, Am. Bar Ass'n, in N.Y.C., N.Y. at 16 (Oct. 16, 2010). 
What about the infamous "ladies' day," and professors who addressed the class as "Gentlemen"; what about the not-a-bit-funny so-called humor, the degrading hypotheticals? When Julius Goebel called on only women during "ladies' day," didn't we march out of the classroom? When Dean Young B. Smith, addressing my entering class, said "It is also true that the average capacity of our student body is very high and included among them are many young men of extraordinary ability," didn't we boo, or hiss, or yell out the 1952 equivalent of "what are we, chopped liver?" Did we not agitate for the admission of greater numbers of women students? Did we not demand the hiring of women faculty? The answer is no- and no and no and no. Or, to be precise, my answer is no, I did not; but to the best of my highly fallible recollection, neither did my classmates. ${ }^{120}$

It is not difficult to understand why women of that era would have been reluctant to speak up. The pervasiveness of discrimination against women in the legal profession made it difficult enough for female law school graduates to find meaningful work. Antagonizing the male faculty at their law schools by pushing back, even gently, against the engrained sexism they encountered could have destroyed any chance of finding a job after graduation.

Nevertheless, cracks in the edifice of male domination of law schools began to emerge in the mid-60s. The number of women in law school had gradually ticked upward. One Harvard Law graduate reported that she thought that Harvard had abandoned its quota system when she entered in 1966, as the dean complained that there were thirty-seven women in that entering class taking up the place of a man. ${ }^{121}$ Nevertheless, the attitudes of many law school administrators still reflected pervasive bias toward women as lawyers. A 1970 study reported that law schools "seemed to emphasize that they had to carefully scrutinize the motivation for the application of a female student to law school more carefully than they scrutinized the motives of a male applicant." ${ }^{122}$ Interviews of female applicants often included those who "commented unfavorably upon the admission of women to law school," or who "seemed doubtful that the applicant would finish the three years of study," or asked about marriage plans, or warned that it would be difficult for the applicant to find a job after graduation. ${ }^{123}$ Despite all this evidence, the author blithely concluded: " $[\mathrm{I}] \mathrm{t}$ is impossible to estimate to what extent the factor of sex influences a law school application." ${ }^{24}$

120. Black, supra note 115, at 1457 (footnotes omitted).

121. Epstein, supra note 51, at 52.

122. Janette Barnes, Women and Entrance to the Legal Profession, 23 J. Legal Educ. 276, 288-89 (1970).

123. Id. at 290 .

124. Id. 
Nevertheless, as political and cultural changes swept through the nation, incoming students became far less willing to tolerate what they saw as archaic authoritarianism in the classroom. ${ }^{125}$ Even Professor Leech's Ladies' Day performance at Harvard Law fell victim to changing times, as the first-year women in the class of 1968 had had quite enough:

[W]e dressed in black, all wore glasses and carried black briefcases. We totally devastated Leech-knew all the answers, and at the end, when he asked, "What was the chose in question?" (his big punch line-the answer was "underwear" and was supposed to embarrass [sic] us), we replied, "we've replevied a few samples," opened our brief cases, and threw fancy lingerie at the "boys." Leach almost had a stroke on the spot, and never had a ladies' day again! ${ }^{126}$

In some law school classes, women now would hiss audibly at professors whose comments they resented. Yet even as women pushed back against unequal treatment, some men took offense at any suggestion that they had been unfair to their female students. When women at one elite law school criticized a professor as "very prejudiced against women," one of his colleagues was horrified. His friend "happened to be one of the most pleasant colleagues. ... [ [I] t must have hurt him badly to have them criticize him." 127

Even as the composition of the student body began to change, the makeup of the tenure-track faculty at most law schools had not. As of 1965 , only about thirty women had ever served as full-time, tenure-track law professors, now countable on six hands instead of one. ${ }^{128}$ At Harvard Law, for example, once Sonia Mentschikoff left for Chicago Law in 1952, there would be no woman on its faculty for the next twenty years. ${ }^{129}$ There is no way to know how many other women might have considered law teaching at the time if the path had appeared to be open to them. When Doris Sassower (1932-2019), a 1955 graduate of New York University Law, told her dean that she was interested in teaching, he told her that:

[T] here was no room on the faculty of a law school for a woman. He said he was surprised that I had such an ambition because he thought it was a well-known fact that law schools did not hire women professors. He told me flatly that my goals were unrealistic and that I should consider something more feasible. ${ }^{130}$

125. EPSTEIn, supra note 51, at 67-68.

126. Id. at 67 (second alteration in original).

127. Id. at 68 .

128. Kay, supra note 20; see also Herma Hill Kay, What I Learned About Feminism from the Early Women Law Professors, 9 Issues in Legal Scholarship 1 (2011).

129. See Basile, supra note 37, at 153.

130. Liz Cameron, Outside In, 5 Barrister 14, 16 (1978). 
For those few women who managed to find a teaching position, fitting into a previously all-male preserve could be quite difficult. Janet Mary Riley (1915-2008), who had served for many years as the law librarian at Loyola University, New Orleans, was promoted to be a member of the fulltime faculty after obtaining her law degree in 1952. She described a phenomenon that still rings true for many women today, remembering that at faculty meetings:

[F] or a long time I had the feeling that I was tolerated, but my opinion was not sought. Sometimes when I expressed my opinion, they shut up long enough to let me finish the sentence and then picked up the conversation where it had been and practically paid no attention to what I had said. Very often I'd hear my opinion expressed fifteen minutes later by another faculty member, as though it were a brand-new idea, and adopted with enthusiasm. ${ }^{131}$

At Wisconsin, Marygold Melli (1926-2018) asked her dean to stop calling the faculty meetings to order by proclaiming "Mrs. Melli and Gentlemen," which surprised him because he "thought he was being nice." 132

Ellen Ash Peters (1930-), the first woman to join Yale's law faculty in 1956, was treated remarkably well by the standards of the time during the following year when she informed the dean that she was pregnant, and to her "surprise and delight," she received the course reduction she requested as an accommodation. ${ }^{133}$ But her later experience proved to be less delightful, when she alone of the eighteen new faculty hired in the mid-1950s was denied tenure, despite what she understood to have been express promises to the entire group that they would be granted tenure "no later than 1960, without regard to scholarly publication or classroom performance." 134 Peters considered resigning, but accepted the dean's offer of additional assistance so that she could "demonstrate the scholarly achievements on which the governing board insisted." 135 By 1964, after a major publication in the Yale Law Journal, Peters received tenure, but she never changed her view that the initial denial had been unfair. ${ }^{136}$

The hiring process for women law professors could be fraught with bias. Herma Hill Kay wore a large-brimmed hat to her first day of interviews at Boalt, only to be told at the end of the day by the only woman on the faculty: "You're going to have to take your hat off. The men want to

131. Miedzian \& Malinovich, supra note 84, at 405.

132. Interview by Joan F. Kessler with Marygold S. Melli, Am. Bar Ass'n at 39 (Fall 2005).

133. Ellen Ash Peters, The Deanship, 113 Yale L.J. 15, 18 (2003).

134. Id. at 19 .

135. Id.

136. Id. 
see what you look like." 137 When Kay objected, the professor relented and told her, "Perhaps when you come back for your second day of interviews, you could wear a smaller hat." 138 Kay expressed surprise that there would be a second day of interviews, and Armstrong looked at her and said: "There will be now." ${ }^{39}$ Fortunately, Kay's small pillbox hat proved to be acceptable to the men, and in 1960 she began a long career at Boalt that culminated in her service as its first female dean. ${ }^{140}$

Black women began to make inroads into the legal academy as well. In 1951, Sybil Jones Dedmond (1921-2013) joined the faculty of North Carolina Central University Law School, becoming the first African American woman to obtain a full-time, tenure track teaching position at a law school. Dedmond had graduated from the University of Chicago Law School in 1950, where she had a positive experience, although there were only seven women in her class and she was the only black woman. She later became the first black woman to obtain tenure at any law school in the country. ${ }^{141}$ Dedmond recalled that her all-male, first-year class did not object to her presence and largely accepted a female law professor.

The second African-American woman to obtain tenure was Patricia Roberts Harris (1924-1985), who had graduated first in her class from George Washington Law School. She joined the faculty at Howard Law in 1961 and would later serve briefly_-for only thirty days-as the first black female dean in the country, before resigning in the midst of controversy over the handling of student protesters in 1969. ${ }^{142}$ Harris was known as a "tough task master," who expected much from her law students. ${ }^{143}$

A third black law professor was Jean Camper Cahn (1935-1991), who joined the faculty at George Washington Law School in 1968 to establish an early clinical opportunity called the Urban Law Institute. After a controversial dispute with the Law School that resulted in the disbanding of the Institute, Cahn and her husband Edgar founded the Antioch Law School in Washington, D.C. in 1972, when they were both thirty-three years old. They were committed to a new brand of legal education, focused largely on poverty law and intense clinical experiences. They served as co-deans until 1980, when the tumultuous conditions in their struggling law school led to their discharge by the board of trustees. ${ }^{144}$

137. Interview with Kay, supra note 87 , at 44 (internal quotation marks omitted).

138. Id.

139. Id. (internal quotation marks omitted).

140. Id.

141. See Elwood D. Watson, Outsiders Within: Black Women in the Legal ACADEMY AFter Brown v. BoARd 49 (2008); see also Emma Coleman Jordan, Images of Black Women in Legal Academy: An Introduction, 6 Berkeley Women's L.J. 1 (1990).

142. See Jordan, supra note 141, at 14-16.

143. Id. at 15 (internal quotation marks omitted) (citing Judy Dimes-Smith, My Tribute to Professor Patricia Roberts Harris, 29 How. L.J. 427 (1986)).

144. Id. at 18. 
At least one women found entry into law teaching to be a relatively smooth experience. Once again, Dorothy Wright Nelson seems to have been that rare outlier who experienced no discrimination at all, reporting that she "got huge raises all the time" and "stopped comparing my salary to some of the young males, because I realized that I was getting more money than they were getting." ${ }^{45}$ She did concede that some of the faculty wives did not appreciate her presence:

I was the only woman on the faculty. So, one after another I invited them to my house to dinner to see my husband, to see my children. I wasn't in competition with their husbands, I wasn't out for it and so forth and became very good friends with the faculty wives. ${ }^{146}$

The best-known of these pioneering women, of course, is Ruth Bader Ginsburg, who joined the faculty of Rutgers Law School in the fall of 1963, when she was thirty years old and had an eight-year-old daughter. ${ }^{147}$ Congress had recently passed the Equal Pay Act, and Ginsburg was startled to learn that she would be paid less than a comparable male member of the law faculty. The dean carefully explained to her: "You know, Ruth, he has a wife and two children to support and your husband has a well-paid job in New York." 148 Seven years later, Ginsburg received an "enormous" pay raise as part of the settlement of a class action lawsuit brought by female faculty throughout various departments at Rutgers. ${ }^{149}$ Ginsburg's concern about gender bias had also led her to conceal her pregnancy in 1965, fearing that she might not have her contract renewed. She explained:

Ten years earlier, when my first child [Jane] was born, it was understood I would leave work and not come back. So I said nothing, but borrowed clothes from my ever supportive, one size larger mother-in-law. With her wardrobe at my disposal, I managed to make it through the spring semester. ${ }^{150}$

Ginsburg received tenure in the fall of 1969 after an article published in the Harvard Law Review but with a mixed vote in her favor. ${ }^{151}$ Within three years, she would move to Columbia Law School to become the first female to receive tenure at an Ivy League law school. Soon thereafter, she

145. Interview with Nelson, supra note 90.

146. Id.

147. See Wendy Webster Williams, Justice Ruth Bader Ginsburg's Rutgers Years: 1963-1972, 31 Women's Rts. L. Rep. 229, 257 (2010).

148. Deborah Jones Merrit \& Wendy Webster William, Transcript of Interview of U.S. Supreme Court Associate Justice Ruth Bader Ginsburg, April 10, 2009, 70 Oнго Sт. L.J. 805, 807 (2009) (internal quotation marks omitted).

149. Williams, supra note 147, at 233.

150. Id. at 234 (alteration in original) (quoting Ruth Bader Ginsburg, Associate Justice, U.S. Supreme Court, Remarks at Rutgers University School of LawNewark 1 (April 11, 1995) [hereinafter Remarks by Ruth Bader Ginsburg]).

151. See id. at 236. 
would become the most effective advocate for women's equality under the Constitution that the nation had ever known.

\section{III. “Token WOMEN": 1970-1980}

Perhaps most surprising to the modern reader may be the fact that sex discrimination in law schools did not violate federal law until the mid60s. ${ }^{152}$ Although the Civil Rights Act of 1964 prohibited discrimination in employment on the basis of sex, its prohibitions originally did not extend to colleges and universities. ${ }^{153}$ One year after its passage, on September 24, 1965, President Lyndon B. Johnson issued Executive Order 11246, which prohibited federal employers and contractors from discriminating in employment because of race, ethnicity, or religion. ${ }^{154}$ Notably, that Executive Order did not include the category of sex discrimination. A concerted lobbying effort by the recently created National Organization for Women (NOW) and other women's organizations ultimately persuaded the President to amend the order. Two years later, on October 3, 1967, Johnson signed Executive Order 11375, forbidding federal employers and federal contractors from discriminating on the basis of sex.

Executive Order 11375 had the potential for an immediate impact on law school hiring. Unlike Title VII of the Civil Rights Act, the Executive Order did not exclude colleges and universities from its reach. At that time, about $80 \%$ of American colleges and universities qualified as federal contractors and were thus covered by the new requirement. The Department of Health, Education, and Welfare (HEW) had the authority to enforce the new order, but initial enforcement lagged, largely due to the reluctance of some in the Nixon Administration to treat sex discrimination with the same degree of concern as other forms of discrimination, particularly with respect to establishing goals and timetables for correcting disparities. ${ }^{155}$

Not content to wait for the federal government to act, the newly organized Women's Equity Action League (WEAL) leapt into action. WEAL had originally been part of NOW but became a separate organization that focused more on economic equality than other controversial social issues like abortion and sexuality. In January 1970, the organization filed an administrative class action under Executive Order 11375, and it eventually would challenge the hiring practices at more than 150 colleges and universities as discriminatory on the basis of sex. ${ }^{156}$ Dr. Bernice Sandler (1928-2019), later to be the architect of Title IX, chaired WEAL's Action Committee for Federal Contract Compliance, which oversaw this enforce-

152. See Donna Fossum, Law and the Sexual Integration of Institutions: The Case of American Law Schools, 7 ALSA F. 222, 224 (1983).

153. See id.

154. See id. at 223-24.

155. See id.

156. See id. at 238. 
ment effort. WEAL's efforts extended beyond pursuing relief through HEW, but also reached legislators in Congress. One of the few female members of Congress, Martha Griffiths (1912-2003) of Michigan took up the cause on the floor of the House in March 1970, explaining the basis for the WEAL lawsuits and challenging the government for dragging its feet in enforcing prohibitions against sex discrimination. Soon thereafter, HEW began its first investigation at Harvard University. ${ }^{157}$

Although some colleges and universities successfully fended off the administrative proceedings, the fact that the federal government had begun to examine long-standing discriminatory practices did not go unnoticed. As Sandler later recalled: "Pandora's Box had finally been opened." 158 By November 1970, more than 2,000 colleges and universities found their hiring practices subject to federal scrutiny, due in large part to what the New York Times described as "[w] omen's liberation activities." 159

Not coincidentally, 1970 also proved to be a watershed year for elevating the visibility of sex discrimination in law schools. At its 1969 annual meeting, the AALS had created a Special Committee on Women in Legal Education, "at least partly in response to petitions by women law students." 160 One year later, the AALS formally established a Section on Women in Legal Education (WLE). Perhaps reflective of the demographic realities at the time is the fact that the first chair of that Section was a man, Daniel Collins, a labor law professor at New York University Law School. ${ }^{161}$ By 1972, however, Ruth Bader Ginsburg had taken over the Section as chair, at a meeting attended by only twelve women. ${ }^{162}$ The WLE soon became an important resource for the small number of women in law teaching at that time, providing a vehicle for those who felt isolated at their home institutions to share their concerns with like-minded colleagues. ${ }^{163}$

The AALS Special Committee met in New York City on April 18, 1970, and proposed that the AALS "prohibit sexual discrimination and . . . require law schools to deny use of their placement facilities to prospective employers who discriminate on the basis of sex."164 The Executive Com-

157. See id.

158. Bernice Resnick Sandler, Title IX: How We Got It and What a Difference it Made, 55 Clev. St. L. Rev. 473, 476 (2007).

159. Richard D. Lyons, Women Forcing Colleges To Give Job Data to U.S., N.Y. Times, Nov. 8, 1970, at 1.

160. Ass'n of Am. Law Schs., Committee Reports, 1970 AALS Proceedings $110(1970)$.

161. See Nancy S. Erickson, The Other One: Life as a Feminist/Female Law Professor, 1975-1987, 80 UMKC L. Rev. 683, 684 (2012); see also Marina Angel, Women in Legal Education III, 80 UMKC L. REv. 711, 711-12 (2012).

162. See Marina Angel, Women in Legal Education: What It's Like to Be Part of a Perpetual First Wave or the Case of the Disappearing Women, 61 Temp. L. Rev. 799, 806 (1988).

163. See Laura Rothstein, Reflections from an Era of Breaking Glass-1984-1998, 80 UMKC L. REv. 757 (2012).

164. Ass'n of Am. Law Schs., supra note 160, at 110. 
mittee of the AALS approved the proposal, "modified to cover all forms of discrimination based on 'race, color, religion, sex or national origin[,]"” and sent it out to law schools in October for action at the 1970 Annual Meeting. ${ }^{165}$ In its report in support of this proposal, the Special Committee noted how few women were serving as law faculty and proposed affirmative steps to recruit more women, noting that "lack of women faculty members has serious adverse effect on recruitment, education and placement of women students." 166 The report also identified the possible need for day care centers for "children of law students, faculty and staff[,]" and sought a "full-scale, professionally administered study of patterns of discrimination among prospective employees." 167

At its annual meeting on December 30, 1970, the AALS opened debate on the antidiscrimination proposal. A few male faculty members openly argued against the extension of this ban on sex discrimination to legal employers who recruited on campus. Professor Neal Murphy of Duquesne Law School expressed "reservations about the coercive aspects of the placement proposal," explaining that " $[\mathrm{w}]$ hile I certainly accept the principle expressed there, I have some doubt about whether it is proper for the law schools to attempt to coerce people outside the law school community to comply with ideals of equal opportunity for women." 168 Similarly, Dean Arthur A. Weeks of Cumberland Law School insisted that although he did "support the women[,]" he was "very much disturbed about this matter of equality. You find very little of it in nature[,]" a remark apparently met by laughter. ${ }^{169}$ He then explained that a federal court of appeals judge had told him that he "insisted from the very beginning on having a black as one of his clerks[,]" but he could not see fit to hire a woman because " $[\mathrm{m}]$ y situation is such, I travel-our close relations, that type of thing could be somewhat embarrassing." 170 Weeks concluded that "when it comes to telling someone who they will employ, that is just simply not the American way to do it, in my opinion."171 Despite these objections, AALS member schools voted to approve the formal policy against sex discrimination in admissions, employment, and placement.

165. Id.

166. Id.

167. Id. at 111 .

168. Id. at 129. In 1995, Duquesne Law School fired Murphy for sexual harassment of first-year female law students, and his termination was later upheld by the U.S. Court of Appeals for the Third Circuit and the Supreme Court of Pennsylvania. See Duquesne Law Professor Loses Appeal of Firing, Pittsburgh Post-Gazette (Dec. 31, 1999), http://old.post-gazette.com/regionstate/19991231duquesne7.asp [https://perma.cc/255U-GN35]; see also Murphy v. Duquesne Univ. of the Holy Ghost, 777 A.2d 418 (Pa. 2001).

169. Ass'n of Am. Law Schs., Proceedings of the Annual Meeting of the Association December 28, 29 and 30, 1970130 (1970).

170. Id. (internal quotation marks omitted).

171. Id. 
Not content to wait for implementation of the new AALS policy, a new organization called the Professional Women's Caucus (PWC) pursued an administrative class action against American law schools in April 1971, alleging sex discrimination in hiring, admissions, and financial aid. ${ }^{172}$ Doris Sassower, former president of the New York Women's Bar Association, organized the PWC, "dedicated to equal rights for women and the expansion of opportunity for women in the professions." 173 HEW continued its investigation of law schools, with Harvard Law School under pressure to remedy the fact that it had no women on its tenured faculty. ${ }^{174}$ Other law schools faced similar challenges and needed to decide whether to "voluntarily take steps to hire women faculty members or wait for the government to force them to do so." 175

After the first year of implementation of the AALS policy on nondiscrimination, many male faculty members still struggled with its implications. Ruth Bader Ginsburg recalled a discussion at the AALS annual meeting in December 1971, when one male colleague "smiled, confident again as law professors often are, and said with assurance, business would go on as usual, nothing significant would change. What were women lawyers after all? Simply soft men."176 Another male professor explained that there were two types of women lawyers:

[T] he social workers, the ones that devote themselves to the poor and the oppressed, the truly needy. That type was not cause for concern. The social workers do not figure at all in the real world of legal business, the professor said. Second, there are the backstagers, women who would find congenial work in drafting wills and contracts, and research and brief writing. The rough-andtumble, knock-down-dragout adversary confrontations would continue, as always, he concluded, with hard men center stage. ${ }^{177}$

Try as some might to wish it away, however, the nearly-all male bastion of the legal academy was about to receive its death blow. Under increasing pressure to act on sex discrimination, on June 23, 1972, President Nixon signed the Higher Education Act of 1972, popularly known as "Title IX," prohibiting discrimination on the basis of sex in any federally funded education program or activity, and including colleges and universities in its

172. See Basile, supra note 37, at 158; see also Fossum, supra note 152, at 238.

173. Doris L. Sassower, Women in the Law: The Second Hundred Years, 57 Ам. B. Ass'N J. 329, 329 (1971); see also Cameron, supra note 130.

174. See Basile, supra note 37; see also Jerry Snow, HEW Spurs HLS To Recruit Woman for Professorship, Harv. L. Rec., Nov. 12, 1971, at 1. At the time, Harvard had four women serving as lecturers or teaching fellows among its ninety-five or so faculty members, including Ruth Bader Ginsburg. Snow, supra, at 2.

175. Fossum, supra note 152, at 239.

176. Ginsburg, supra note 50, at 274.

177. Id. 
scope. Following suit, in August 1972, the ABA adopted a strong antidiscrimination resolution aimed at law schools, urging that "all law schools should: (a) make substantial efforts to recruit and admit women students, (b) make substantial efforts to recruit, hire and promote women professors, (c) require that their placement services be made available only to potential employers who hire on a nondiscriminatory basis," and further urging " $\mathrm{t}]$ hat law firms and other employers refrain from discriminating against women attorneys with regard to hiring, assignment and promotion of women lawyers." 178

In late 1972, HEW stepped up its enforcement efforts, forwarding a memorandum detailing the requirements of Executive Order 11375 to the heads of every American college and university.

By 1973, investigations had been conducted at almost two hundred universities and colleges and the awarding of new government contracts to about forty of them had been temporarily delayed, most often as a result of refusal to provide access to information needed to conduct the investigations or failure to develop satisfactory affirmative action plans. During the investigation of Columbia University the government was, for the first time, forced to initiate proceedings to terminate existing government contracts as well as stop awarding new contracts until Executive Order 11375 was complied with. ${ }^{179}$

The University of Chicago Law School was subject to a 1973 finding that "the law school's 'placement service unlawfully discriminates against females, as a class, by denying them equal employment opportunities and that it failed to fulfill its duty to insure equal treatment of women." 180

Over the next few years, the gender composition of law schools, both in their student bodies and their faculties, changed substantially. In 1970, there were 13,000 female attorneys in the country. In 1976, there were 38,000 , and by 1980 , there were $62,000 .{ }^{181}$ Thus, during the decade in

178. Shirley Raissi Bysiewicz, 1972 AALS Questionnaire on Women in Legal Education, 25 J. Legal Educ. 503, 503 n.1 (1972); see also D. Kelly Weisberg, Women in Law School Teaching: Problems and Progress, 30 J. Legal Educ. 226 (1979); Cameron, supra note 130, at 17. There is some suggestion that the ABA's Board of Governors originally voted down this proposal, which was later approved by the ABA House of Delegates. Cameron, supra note 130, at 17.

179. Fossum, supra note 152, at 238-39.

180. Timothy D. Rudy, Note, UC Appeals EEOC Charges of Sex Discrimination, 6 Student L. 25, 27-28 (1973) (regarding University of Chicago student discrimination suit).

HEW found that, although in the last five years the school has failed to hire women and minorities as junior and senior faculty, the school has actively employed women in its Mandel Legal Aid Clinic and Woodlawn Legal Aid Clinic and as Bigelow Teaching Fellows (as instructors in the legal writing program).

Weisberg, supra note 178, at 243 n.34.

181. Epstein, supra note 51, at 4 . 
which sex discrimination in law school admissions became illegal, the number of women lawyers more than quadrupled. The reasons for these developments are complex, but the seismic reordering of the regulatory landscape cannot be underestimated, even as it accelerated patterns that had already begun. There had already been a sizeable increase in the number of women attending law school in 1970, even before the AALS adopted its antidiscrimination policy (but after the federal government had made it illegal for recipients of federal money). ${ }^{182}$ Some law school administrators had begun to take into account the loss of potential revenue because of the effect of the Vietnam-era draft on potential male applicants and were admitting more women to compensate. ${ }^{183}$ In addition, the handful of law schools that still excluded female students could no longer justify their discriminatory policies. Notre Dame Law School had finally admitted women as law students in 1969. The last holdout, Washington \& Lee Law School, finally changed its policy in 1972 (not coincidentally, the same year that its university graduated its first African-American students), apparently under threat of losing its ABA accreditation. ${ }^{184}$

Of necessity, law school faculties began to reflect these changes. " $[\mathrm{T}]$ he percentage of law schools with tenure track women faculty members increased quite dramatically shortly after the issuance of Executive Order 11375. Specifically, starting in 1970 and each year thereafter the percentage of law schools with women on their tenure track faculties accelerated." 185 Not only were law schools under pressure from the federal government, but they also now faced an increasingly restive population of young women who had been affected by the revived women's movement. Wendy Williams recalled that Georgetown Law made her an offer in late 1975-early 1976:

[B] ecause Georgetown's women students had founded a women's collective, as they called it, and began pressing the school administration to hire more women on the faculty and, specifically, a woman with my expertise in women and law. They had been getting along by importing adjuncts to teach women and the law. ${ }^{186}$

The number of women entering law teaching during this period must have seemed like a torrent to previously all-male faculties, even though the progress seems glacial to modern eyes. In 1974, for example, law schools

182. See Fossum, supra note 152, at 230, 233.

183. See id. at 233.

184. See John Witt, Roster of Men's Colleges Dwindles as Old Washington Eं Lee Goes Cold, UPI (July 31, 1984), https://www.upi.com/Archives/1984/07/31/Roster-ofmens-colleges-dwindles-as-old-Washington-Lee-goes-cold/9883460094400/ [https: //perma.cc/FD99-3QRZ]; see also Millard H. Ruud, That Burgeoning Law School Enrollment Slows, 59 Ам. В. Ass'n J. 150 (1973).

185. Fossum, supra note 152, at 235.

186. Interview with Williams, supra note 87 , at 65 . 
hired fifty-five women as tenure-track or tenured law professors. By comparison, in the fifty years from 1919 to 1969 , only fifty-one women had ever received such positions. ${ }^{187}$ Before attributing the increased hiring to the increased pool of female law school graduates, it is important to recall that many law schools had previously hired women for non-tenure track positions, and so some schools simply moved women who were already serving on the faculty in those capacities to tenure-track positions. ${ }^{188}$ In addition, the traditional pattern of hiring women as law librarians had held constant, comprising $30 \%$ of law librarians. ${ }^{189}$

Many of the women who entered law teaching in these early days were "strong feminists," recalled Nancy Erickson, explaining:

Many of us came out of the civil rights, women's liberation, and anti-war movements (for me, all of them, but women's liberation predominantly). At Brooklyn Law School we had no women professors and faced blatant sexism in every course. Those of us who managed not only to survive but also to go on to law teaching were few and far between. ${ }^{190}$

What was the experience like for this first critical mass of women faculty flooding into American law schools? Many women understood that they had been hired in order to desegregate all-male faculties and either regretted (or embraced) the notion that they were "tokens." Martha Craig Daughtrey (1942-) ruefully recalled that when she arrived as a faculty member at Vanderbilt in 1972, "I was the first and the only woman on the law faculty, undoubtedly the beneficiary of some early affirmative action in hiring, and as the comedienne Minnie Pearl would say, I was 'just so proud to be there." 191 Ellen Solender (1924-2015) also remembered that she was hired as a "token woman" by Southern Methodist in 1972 but reminded herself that she "really was qualified and should have been hired on my merits."192 Stephanie Wildman (1949-), who joined the faculty of the University of San Francisco School of Law in the mid-1970s, later mused:

Reflecting now, I realize that if many of us hired in that era had been asked, "Do you want a job integrating the academy by race

187. Kay, supra note 20 , at 15 .

188. Fossum, supra note 152, at 239.

189. Weisberg, supra note 178, at 235-36 ("It has been noted that women lawyers gravitate toward law librarianship because this is an area of the profession where discrimination is less pronounced."); see also Beatrice Dinerman, Sex Discrimination in the Legal Profession, 55 Aм. B. Ass'N J. 951, 952 (1969).

190. Erickson, supra note 161 , at 683-84.

191. Martha Craig Daughtrey, Women and the Constitution: Where We Are at the End of the Century, 75 N.Y.U. L. REv. 1 (2000). She was a 1968 graduate of Vanderbilt and later would serve on the United States Court of Appeals for the Sixth Circuit.

192. Ellen K. Solender, The Story of a Self-Effacing Feminist Law Professor, 4 Ам. U. J. GENDER \& L. 249, 252 (1995). 
and gender?" we would have said, "Are you crazy? You can't pay us enough." But that is the work we were doing. In my first year teaching, only two colleagues came to talk to me in my office: the other two affirmative action hires-a black man and a Latino. ${ }^{193}$

Unlike the bureaucratized process of applying for law professor positions today, faculty hiring in the 1970 s was quite informal, a process that had previously limited the opportunities of women. Many women hired during this period had been recruited to apply by friends or work colleagues. A friend on the Georgetown Law faculty recruited Patricia King (1943-) to teach an evening course as an adjunct professor in 1972. She then accepted a one-year visiting position before she became the second African-American woman to be hired as a tenure-track faculty member by Georgetown, at a time when " $[y]$ ou could count on one hand the number of African American professors in the nation." 194 Stephanie Wildman received a call from the University of San Francisco Law School in 1974 from the appointments chair, who openly told her that the school was recruiting women to its faculty. Her first reaction had been, "I said 'no,' thinking, 'Who would want to be a law professor?' I knew what law professors looked like: old men. I had no imagination. But USF said, 'Don't say no, have lunch with us." "195

In 1972, Sheila Birnbaum received a more candid call from an acquaintance at Fordham Law, who asked her for "a big favor," because "we are getting a lot of grief from the women students because we don't have a woman professor. And, we really need to interview some women. We are not really necessarily interested in hiring them, we're interested in interviewing." 196 Birnbaum initially turned down this unattractive pitch, but she later relented and joined the Fordham faculty in 1974.

Issues about "qualifications" for entering law professors inevitably raised the pervasiveness of sex discrimination in the legal profession, which hampered the ability of many women to obtain certain credentials. For example, the position of editor in chief of a law review rarely went to a woman. The Columbia Law Review had only had two women serve as editor in chief in forty-eight years, Harvard Law Review had only one since it admitted women in 1950, and the California Law Review had not had a woman editor in chief since $1916 .{ }^{197}$

193. Stephanie M. Wildman, Gender Integration of the Legal Academy: The Role of the AALS Section on Women in Legal Education, 80 UMKC L. REv. 801, 802 (2012).

194. Interview with King, supra note 116, at 7 (Aug. 8, 2007). Anita Martin had preceded King in 1972 as the first African-American woman on the Georgetown faculty, but she left in 1974. Id.

195. Wildman, supra note 193 , at 801.

196. Interview with Birnbaum, supra note 119, at 26-27.

197. Weisberg, supra note 178, at 240. 
It could also be difficult for women law students to form the necessary mentoring relationships with faculty members to obtain recommendations for prestigious clerkships. One professor candidly explained in 1979:

A woman is in a very peculiar situation. If she is outspoken and stands out, she's typed as an "old style" woman lawyer-obnoxious and aggressive. If she's quiet in a classroom, her professors will say [when asked to recommend her] "she didn't impress me very much." 198

In addition, the reluctance of some judges to hire women as law clerks made it more difficult for female candidates to compete on equal footing with male candidates for faculty positions. As of 1971, only three women had ever served as Supreme Court law clerks. ${ }^{199}$ Ruth Bader Ginsburg had been passed over by Justice Felix Frankfurter because he was not ready to hire a woman, and generally there were "plenty of judges who simply won't take women." 200 Wendy Williams pursued a clerkship with federal district court judge Alfonso Zirpoli, but when she asked him "nicely" whether it was true that he did not hire women as clerks, he "started mumbling about his secretary. I couldn't quite tell what he was saying, but it was something about how secretaries didn't like to work for other women." 201

Other women law students reported similar experiences during this time period. One judge exclaimed upon meeting a female clerkship candidate: "My God, it's a woman!"202 In addition to blaming secretaries as the opponents of additional women in chambers, some judges had informal quotas of not hiring more than one woman as a clerk at a time. Most absurd may have been the judge who patiently explained to a female applicant: "Sometimes we have to move the F.2d's around and we need a man to do that."203

Even if a female candidate managed to meet the preliminary "qualifications" and obtain an interview at a law school, the hiring process often was infected with overt stereotyping, sometimes couched in the question: "What type of commitment does this woman have to law?"204 Some faculty members would be skeptical of a female candidate whose "husband is making plenty of money," or worry that the woman would "get pregnant and leave." 205 Open assessment of applicants based on their appearance was common, as one female law professor reported:

198. Id. at 242 (alteration in original).

199. Ginsburg, supra note 50, at 273.

200. Weisberg, supra note 178, at 239 (quoting Roger M. Williams, Law Schools: The Big Woman Boom, SAturday Rev. World, Sept. 21, 1974, at 54).

201. Interview with Williams, supra note 87, at 28-29.

202. Weisberg, supra note 178, at 239 (internal quotation marks omitted).

203. Id. (internal quotation marks omitted).

204. Id. at 242 (internal quotation marks omitted).

205. Id. 
The type of woman they like at my school is one not too aggressive personally, not too threatening in a social way. I hate to say it, but it helps if you flirt and you're pretty ... [.] The number one comment here when male faculty review the files is "what does she look like?"206

In fact, male professors sometimes would make disparaging remarks such as "I can't work with anyone that ugly." ${ }^{207}$ In the early 1980s, Rochelle Dreyfus reported that "[i]nterviewers frequently asked questions such as What does your husband do? or What are your children doing? - which were not asked of male clerks being interviewed." 208 She was then clerking for Chief Justice Warren Burger and had been the editor in chief of the Columbia Law Review, and has been on the faculty of NYU Law since 1983.209 A dean once explained to a female colleague who was urging him to hire more women that "there is no problem finding qualified women. The problem is that they depreciate too rapidly." 210

On occasion, the opposition to hiring women came from female faculty hired in earlier decades who could be unsympathetic to the new generation of women entering the legal academy. In 1973, Soia Mentschikoff warned Ruth Bader Ginsburg that "law schools, in their haste to get 'their woman' for the faculty would take women who were not the strongest candidates and then would say to later applicants, 'We had a woman once, and she was unsuccessful.'"211 Mentschikoff, the presidentelect of the AALS, argued that:

[T] he law schools [should] delay their recruitment of women faculty for about five years, when she believed that an abundant supply of "qualified" women would have graduated from law schools and become available for faculty positions. ${ }^{212}$

At Georgetown Law, the longest serving female faculty member, Helen Steinbinder (1923-2015), did not welcome the new women joining the faculty, accusing Wendy Williams during her interview of being "one of

206. Id.

207. Id. (internal quotation marks omitted).

208. David Lauter, Gender Gap Gets Wider on Law Faculties; Barriers Remain for Women, 6 NAT'L L.J. 12 (1984).

209. Id.

210. Marilyn J. Ireland, Women's Entry into the Law Teaching Profession: Cracking the Door Open, 80 UMKC L. Rev. 695, 697 (2012) (internal quotation marks omitted).

211. Herma Hill Kay, Ruth Bader Ginsburg, Professor of Law, 104 Colum. L. Rev. 1,4 (2004).

212. Id. "Ginsburg had not thought about the matter from Mentschikoff's perspective, but on reflection found much to be said for her view." Id. Mentschikoff also described affirmative action for women as "insulting" in a 1982 interview. See Kay, supra note 20, at 12-13. 
those feminists," or as Williams recalls, "baby killer was more her view of it. She also told me she'd heard that all feminists were lesbians." 213

For the women who managed to survive the hiring gauntlet and obtain faculty positions, the "very male atmosphere" in many law schools proved to be a significant challenge. ${ }^{214}$ When she started at Georgetown Law, Patricia King knew that the Associate Dean for Academic Affairs "didn't enjoy having women on the faculty." 115 She believed that her course package, which consisted of three unconnected courses, Advanced Civil Procedure, Corporations, and Constitutional Law II, reflected his opposition. She did note, however, that she had found her initial salary to be quite fair, even though "women were often underpaid in those years." 216 Other women experienced overt pay discrimination. Ellen Solender had received a modest pay increase when she converted from a part-time to a full-time faculty position, and the total pay was "significantly less than the going rate for entry level faculty." ${ }^{17}$ When she raised the issue with her dean,

[he] replied "This is a real full-time job and you can't act like a volunteer and quit because you don't need the money." I answered that I did need the money. I would soon have three children in college and I was not doing this for fun! The Dean said, "I hear you," but he must not have, since I continued to receive only the prescribed increases based on a percent of base pay. ${ }^{218}$

Even as women began to obtain tenure track positions, the subject matter assigned to them often seemed to reflect some gender stereotyping. A study reflected that in 1975 women were "overrepresented in the areas of family law and legal research and writing but not in the area of trusts and estates," while they were

underrepresented in the areas of corporations/securities/business organizations and antitrust, but not in the areas of commer-

213. Interview with Williams, supra note 87 , at 69 . Williams recalled that "there was a way in which she later seemed proud of us, Judy [Areen], Pat [King] and me. She never changed her view on abortion, but she made her peace with us. But at the time, it was a pretty unpleasant experience for me." Id. For whatever reason, Steinbinder had never been a well-respected member of the Georgetown faculty, and perhaps this status fueled her hostility to the new women recruits coming to the law school. See Interview by Marna S. Tucker with Judith A. Winston, Am. Bar Ass'n at 83 (May 2, 2006); Interview with Tucker, supra note 83, at 1-2 (Sept. 8, 2006).

214. Interview with King, supra note 116, at 12 (Aug. 8, 2007).

215. Id. at 5 .

216. Id. at 11 .

217. Solender, supra note 192, at 252.

218. Id. at 252-53. Despite this unfair treatment, Solender left $\$ 2$ million to the law school. 2015 News Archives, \$2 Million Gift from SMU Almuna, Emeritus Professor to Endow Faculty Chair in Women and the Law, SMU (May 5, 2015), https:/ /www. smu.edu/News/2015/ellen-k-solender-gift-to-law [https://perma.cc/VZ4F-SHG7]. 
cial/banking law and contracts. In the 28 substantive areas of law teaching examined herein, men law professors were significantly overrepresented in 12, or almost half, of the areas and women in only 3 areas. $^{219}$

The law school atmosphere could be difficult for women. Many women resisted having lunch with their colleagues in the faculty lounge, when "the conversations were usually about sports and sometimes politics. . . . The conversations were not really might [sic] cup of tea."220 Martha Daughtrey had lunch her first day at Vanderbilt with two young colleagues, expecting them to be open to the cause of women's rights. When she brought up the ERA, they informed her that it was an "an effort to 'junk up the Constitution,' . . . that would result in trivializing the field of equal protection. They were solidly against ratification."221

Faculty meetings could also have the effect of reemphasizing the isolation of women at law schools. Sometimes well-meaning but obtuse men would quip about women talking to other women as a "conspiracy," even if their only predicate act was to walk into a faculty meeting together. Some male colleagues would accuse women of "getting together before a faculty meeting and deciding to vote as a block, because we happened to agree with each other on something in the meeting. We hadn't. Yes, they did get a little threatened if you seemed to be seeing eye-to-eye or spending time together." 222 Women faculty could also find themselves treated as if they were "invisible," as Wendy Williams noted: "If we said anything in a faculty meeting, the next guy who talked would invoke what the guy who spoke before us said (or attribute to him something we said)."223

Women faculty members would also experience commentary on their appearance, which sometimes degenerated into sexual harassment. At Southern Methodist University Dedman School of Law, a faculty colleague asked Ellen Solender about the color of her underwear, and she also noted the pervasive commentary on the appearance of female law students. "Body-parts were almost always a topic of conversation, particularly when discussing the entering female students. The faculty would make comments about '[t]he blonde with the big boobs.' If there were several students who might fit that description, then they would get more and more graphic. It was quite chilling." 224 Marina Angel's frustration with her male colleagues' sexual comments about female students boiled over at one lunch, when she tartly described a male student in similar terms, to

219. Fossum, supra note 49, at 912-13. "[W] omen were teaching a disproportionate number of courses in the area of constitutional law, a fact that is perhaps surprising until one considers that this area encompasses civil rights and discrimination law, topics obviously of special interest to women." Id. at 912.

220. Interview with King, supra note 116, at 12 (Aug. 8, 2007).

221. Daughtrey, supra note 191, at 3.

222. Interview with Williams, supra note 87 , at 75 .

223. Id.

224. Solender, supra note 192, at 262 (alteration in original). 
"shocked silence." 225 Wendy Williams reported that one of her female colleagues had been subjected to open harassment, including the head of the tenure committee "chas[ing] her around his desk."226

Despite dramatic increases in the number of women law students, the classroom remained heavily male during this time period. Lani Guinier (1950-) recalled how alienating her experience as a student at Yale Law School had been. In 1974, she took a corporations course with a white male professor who addressed the entire classroom each day as "Gentlemen," explaining:

He had been teaching for many years; he was a creature of habit. He readily acknowledged the presence of the few 'ladies' by then in attendance, but admonished those of us born into that other gender not to feel excluded by his greeting. We, too, in his mind, were simply gentlemen. ${ }^{227}$

Three of the women on the Georgetown Law faculty felt the need to consult with an expert on how to manage those dynamics, where "the men in the class would challenge our authority in some way. Some male student would come forward to challenge you the first week. If you survived that, good. If you didn't, you'd have to struggle because then the wolves would really come out. It was fascinating, that psychology." ${ }^{28}$ On the other hand, women students often "took great pride that there was a woman professor and that she was popular and could teach well. It was not only about having a woman but it was having a woman that you could relate too [sic]."229

Pregnant women faculty could become a particular source of conversation for law students. The lack of meaningful maternity leave policies left many women trying "very hard to time our deliveries so we could return to teaching." 230 One woman recalled that her students left an apple on her podium every day during her pregnancy, as her pregnancy was a "topic of great fascination,.... [because] a pregnant law professor just seemed incongruous to students." 231

225. Angel, supra note 162 , at 824 .

226. See Interview with Williams, supra note 87, at 67. According to Williams, Judith Areen experienced substantial harassment: "And then there was a picture of her, a nude figure, with her head superimposed ... [p] osted on a wall at the law school. These were things that happened to her because she was drop-dead gorgeous and in a job a woman wasn't supposed to have." Id. Areen would later serve as the first female dean at Georgetown. See id.

227. Lani Guinier, Of Gentlemen and Role Models, 6 Berkeley Women's L.J. 93, 93 (1990).

228. Interview with Williams, supra note 87 , at 72.

229. Interview with Birnbaum, supra note 119, at 30; see also Stephanie Wildman, Gender Integration of the Legal Academy: The Role of the AALS Section on Women in Legal Education, 80 UMKC L. Rev. 801 (2012).

230. Interview with King, supra note 116, at 13 (Aug. 8, 2007).

231. See Herma Hill Kay, UC's Women Law Faculty, 36 U.C. Davis L. Rev. 331, 367 (2003). 
Women faculty on the tenure track sometimes found it difficult to discern how to meet whatever unspoken requirements might be imposed on them. Some schools had begun to implement heightened scholarship requirements for tenure, although it is unclear whether some of this movement was an unconscious reaction to concerns that some new faculty colleagues were "unqualified." Patricia King felt that she had been "caught in this changed scholarship standards situation where the faculty did want more than one piece of writing but the school didn't know quite how to do it." 232 She decided against taking the dean's offer to extend her time on the tenure clock, noting:

My approach as an African American is to think carefully about the benefits and costs of differential treatment. Yes I wanted to be on the faculty but either I was going to get it done or I wasn't. You reach these crossroads in life and to tell you the truth you must decide. ${ }^{233}$

Wendy Williams had been warned by both Herma Hill Kay and Ruth Bader Ginsburg to stay away from writing about women's rights until she obtained tenure, but decided "that was just not me." ${ }^{334}$ At NYU, one man objected to awarding tenure to a female colleague because he could not "stand her voice! It's too high pitched!" Sheila Birnbaum responded: "That is how women sound!" She explained later: "It was very important to have women in the room because they [sic] some men couldn't say what they wanted to say-and when they said it, if you called them on it, it embarrassed them and then they wouldn't say it again. It did make a difference." 235

For black women, the struggles were even more pronounced. Joyce Hughes (1940-) joined the faculty of the University of Minnesota Law School in 1971, where she had excelled as a student. She became the first African-American woman to be hired as a tenure-track professor at a majority white law school. ${ }^{236}$ Hughes later recalled her difficult first year, when students reacted to her presence with great hostility, and the administration oversaw an "adversarial meeting" to assess her performance, after which "the faculty apologized for subjecting a colleague to such treatment." 237 She found particularly objectionable her dean's assertion that she was somehow deficient because she "did not care to participate in the life of the law school." 238 Hughes later described her experience as "hor-

232. Interview with King, supra note 116, at 15 (Aug. 8, 2007).

233. Id.

234. Interview with Williams, supra note 87, at 67.

235. Interview with Birnbaum, supra note 119, at 31.

236. Biography of Joyce Hughes, History Makers, https://www.thehistory makers.org/biography/joyce-hughes-39 [https://perma.cc/4B7F-Y9XL] (last visited May 4, 2020).

237. Jordan, supra note 141, at 21.

238. Watson, supra note 141, at 54 (internal quotation marks omitted). 
rendous."239 Taunya Lovell Banks entered law teaching in 1976 and noted that law schools were "rampant with tokenism." 240 Linda Greene entered law teaching in 1978 at Temple Law and later recalled that she "was not prepared to relive Jackie Robinson's 1947 experiences 30 years later." 241 She was one of only about a dozen black women in law teaching at the time, and found her experiences to be "painful," as she began "to fear this almost daily assault on my psyche." 242 Greene described an example of what black female professors often endure:

African American female colleagues reported being shouted down in the classroom by white males, being shunned by colleagues, having her teaching qualifications openly challenged in the classroom, receiving anonymous and detailed hate notes critical of her teaching style, syntax, and appearance, and learning of colleagues who had encouraged students to act disrespectfully toward her. ${ }^{243}$

Patricia King noted the double bind that black women law professors experienced, explaining that the "combination [of being black and female] is deadly, or can be deadly. I catch it from both sides." ${ }^{244}$ She relayed the following anecdote:

As one student expressed it, "I do not know how to deal with you. I don't know how to respond in class." And, when I asked why, I was told, "I have never in my life had a Black professor, I have never in my life had a female professor and the combination I just can't deal with." I didn't laugh. I thought that it was an amazingly honest and forth right student who was really trying to overcome his difficulty and deal with a Black in a position of authority. ${ }^{245}$

Taunya Banks recalled that Mildred Robinson of Florida State Law School and Marilyn Yarbrough of Kansas Law School were occasionally called by each other's name by white colleagues. ${ }^{246}$

239. Katherine L. Vaughns, Women of Color in Law Teaching: Shared Identities, Different Experiences, 53 J. Legal Educ. 496, 497-98 (2003) (internal quotation marks omitted) (citing Joyce Hughes, Different Strokes: The Challenges Facing Black Women Law Professors in Selecting Teaching Methods, 16 Nat'L Black L.J. 27, 33 (1998-2000)).

240. WATSON, supra note 141 , at 56.

241. Linda S. Greene, Tokens, Role Models, and Pedagogical Politics: Lamentations of an African American Female Law Professor, 6 Berkeley Women's L.J. 81, 83 (1990).

242. Id.

243. Id.

244. Marilyn Ainsworth et al., Report of Minority-Group Law Teachers Planning Conference, 4 BLACK L.J. 575, 584 (1975).

245. Id. at 85 .

246. WATsOn, supra note 141 , at 56 . 
Despite the many barriers that impeded this generation of female law professors, the influx of women into law teaching had a substantial effect on the curriculum in many law schools. The reemergence of feminism in the 1960s and 1970s, culminating in the passage of the Equal Rights Amendment by both houses of Congress in late 1972, had placed issues of women's equality on the national agenda. Many women law students became frustrated with traditional law courses that did not speak to their particular concerns about sex discrimination, including their treatment in the law school classroom and the legal workplace. ${ }^{247}$ They organized women's rights committees in the law school and began to agitate for greater recognition. Many of the recently hired women faculty members came from the emerging feminist movement, and some had litigated sex discrimination cases in the courts. Prior to the 1970s, few legal scholars showed any interest in a systematic study of sex discrimination. ${ }^{248}$ During the next decade, there was a concerted effort to ensure that law schools taught courses on sex discrimination.

Susan Deller Ross was among the initiators of what appears to have been the first such course at New York University Law School in 1969. Several schools quickly followed suit. Female law students at Yale Law School successfully lobbied the administration to recruit Barbara Babcock to teach a similar course in the spring of 1971 that she had begun at Georgetown Law. Ross then relocated to the District of Columbia, and her team taught the course at George Washington Law with Judge Gladys Kessler. At Berkeley Law School, students demanded a similar course, which would ultimately be taught by Herma Hill Kay. Later, former Boalt students such as Wendy Williams taught similar seminars at Santa Clara, Stanford, the University of San Francisco, and Golden Gate University Schools of Law. 249

The initial process of developing these courses could be laborious. In 1970, while preparing to teach a sex discrimination course at Rutgers, Ruth Bader Ginsburg "repaired to the Library" and later stated "in the space of a month, I read every federal decision ever published involving women's legal status, and every law review article. That was no grand feat.

247. See generally Aleta Wallach, Genesis of a Women and the Law Course: The Dawn of Consciousness at UCLA Law School, 24 J. Legal Educ. 309, 309-12 (1971).

248. Katharine T. Bartlett, Feminist Legal Scholarship: A History through the Lens of the California Law Review, 100 CALIF. L. REv. 381, 383 (2012). "Of note, the most frequently cited article ever published by the California Law Review set forth in 1949 the basic framework for modern equal protection doctrine, without naming sex among the categories that might someday warrant special scrutiny." Id. at $383 \mathrm{n.8}$; see also Joseph Tussman \& Jacobus tenBroek, The Equal Protection of the Laws, 37 CAlif. L. Rev. 341, 355 (1949) ("Candidates [as forbidden classifications] today might be designated with relative ease-race, alienage, color, creed. . . One would hesitate to close the list arbitrarily and foreclose the future.").

249. Linda K. Kerber, Writing Our Own Rare Books, 14 YAle J.L. \& FEMinisM 429, 432 (2002) (quoting E-mail from Wendy Webster Williams to Linda K. Kerber, May Brodbeck Professor in the Liberal Arts and Professor of History, Lecturer in Law, Univ. of Iowa (Dec. 13, 2002) (on file with author)). 
There were not many decisions, and not much in the way of commentary." ${ }^{250}$ The movement for introducing this material into the curriculum accelerated in 1971, when a conference at Yale Law on "Women and the Law" generated the first rudimentary notes for a casebook. The " $[y]$ oung, feisty and marginal" attendees circulated "a fragile 34-page mimeographed packet" entitled "Women and the Law: A Collection of Reading Lists." 251 Historian Linda Kerber explained that this was "a strategy of feminist scholars in the early 1970s. As we engaged in the invention of a subject that our seniors were certain did not exist, we needed to know that we were not alone, and we needed each other's advice. Syllabi circulated in samizdat." 252 During this same time period, the first Women's Rights Law Reporter was published. ${ }^{253}$

In October 1972, the AALS cosponsored a symposium with NYU Law on The Law School Curriculum and the Legal Rights of Women. Participants not only discussed the desirability of including courses on Women and the Law but also talked about ensuring that issues of particular interest to women were adequately addressed throughout the curriculum. ${ }^{254}$ Thomas Emerson argued that constitutional law courses should be covering the Equal Rights Amendment, whose ratification he described as "inevitable." Gerald Gunther seemed surprised that many law professors did not cover sex discrimination in their constitutional law classes, exclaiming: "Is that really a problem? Is it really possible that anyone teaching constitutional law today is not covering sex discrimination? What are they doing, using notes that are fifteen years old?" 255

Within a few years, two textbooks appeared on the scene that facilitated bringing courses on sex discrimination into the mainstream curriculum. New Mexico Law School professor Leo Kanowitz (1926-2007) published Sex Roles in Law and Society in 1973.256 In 1974, West Publishing Company issued Sex-Based Discrimination, authored by Herma Hill Kay, Ruth Bader Ginsburg, and Kenneth Davidson. ${ }^{257}$ Little Brown soon followed in 1975 with Sex Discrimination and the Law, an outgrowth of the mimeographed packet circulated at the Yale Law symposium, co-authored by Barbara Babcock, Ann Freedman, Eleanor Holmes Norton, and Susan

250. Williams, supra note 147, at 241 (quoting Remarks by Ruth Bader Ginsburg, supra note 150).

251. Kerber, supra note 249, at 429 (third internal quotation marks omitted). 252. Id. at 430 .

253. See Elizabeth Langer, Seizing the Moments: The Beginnings of the Women's Rights Law Reporter and a Personal Journey, 30 Women's Rts. L. Rep. 592, 601 (2009).

254. See Daughtrey, supra note 191, at 12-13.

255. News About Women in Legal Education, Ass'n Am. L. Schools (Ass'n of Am. Law Schs., Washington, D.C.), Dec. 1, 1972, at 4 (internal quotation marks omitted).

256. Daughtrey, supra note 191, at 12.

257. Bartlett, supra note 248, at 386 . 
Deller Ross. ${ }^{258}$ That textbook began with the words: "This is not a usual law school text. It did not grow out of the scholarly interests of law professors, but rather had its genesis in student-generated courses in Women and the Law."259 It further warned its readers that they would "encounter explicit bias." 260

It was of critical importance to have textbooks for a field that was not recognized as legitimate by many law professors. As one reviewer noted: "The mere existence of these casebooks has legitimated the discipline itself and has made easily accessible the materials needed to facilitate the teaching of the growing number of law school courses on Women and the Law."261 This was particularly important because of the resistance of many law schools to accepting this new course as part of the curriculum. One young untenured professor reported that "her Dean had been unwilling to let her offer a course in Women and the Law, because he couldn't understand what there was to teach after the first day of class. When she brought [the Kay textbook] to show him, he gave his permission."262 Susan Deller Ross received similar criticism from a colleague at George Washington Law, who informed her: "Now there is nothing to teach in that course-what would you teach?"263 At other schools, the administration proved to be more of a barrier. Georgetown Law administrators cancelled a well-received night course on Women and the Law, team-taught by local attorneys Marna Tucker and Brooksley Born, arguing that there was "no demand for the class," although the attorneys believed that the class was cancelled "because we were women and the course was very threatening to some folks in the law school."264 Nevertheless, the demand for these courses had grown sufficiently that the Exxon Corporation donated money to the Women in Legal Education section of the AALS to produce 15 thirty-minute films on women and the law, which would become the first law school course ever offered as a video course. ${ }^{265}$

By the end of the ' $70 \mathrm{~s}$, women had made their mark within the legal academy, although their numbers remained small. By the 1979-1980 academic year, women held about $10.5 \%$ of the tenure-track or tenured posi-

258. See Kerber, supra note 249, at 430; Christine A. Littleton, Whose Law is this Anyway? Gender and Law: Theory, Doctrine, Commentary by Katharine T. Bartlett, 95 Mich. L. Rev. 1560, 1566 (1997).

259. Kerber, supra note 249 , at 431 (internal quotation marks omitted).

260. Id. at 433 .

261. Herma Hill Kay, Claiming a Space in the Law School Curriculum: A Casebook on Sex-Based Discrimination, 25 Colum. J. Gender \& L. 54, 58-59 (2013) (quoting Aleta Wallach, Book Review, 10 Harv. C.R.-C.L. L. Rev. 252, 254 (1975)).

262. Id. at 59.

263. Interview with Susan Deller-Ross at 11 (July 8, 2003) (internal quotation marks omitted), https://www.law.edu/_media/imported-media/NACLE/dellerross.pdf [https://perma.cc/72F9-627E].

264. Interview with Tucker, supra note 83, at 12.

265. Elizabeth F. Defeis, Women in Legal Education Section, 80 UMKC L. REv. 679, 680-81 (2012). 
tions in law school. Although this may seem abysmally low, it roughly correlated to the $11 \%$ of American lawyers who were women, and it also reflected more than quadruple the $2.2 \%$ of women law professors in 1970. ${ }^{266}$ Underlying these numbers, however, was a more complex story about integrating law school faculties. A handful of law schools with more than $15 \%$ of women on their faculties skewed these numbers, including Antioch Law School in Washington, D.C. (26\%), University of California Davis $(25 \%)$, and North Carolina Central (44\%). ${ }^{267}$ Indeed, of the 164 schools studied by one researcher, 80 schools had either one woman or none at all, leading to concerns about "tokenism." The elite law schools (other than NYU) generally had far fewer women than the national average. More tellingly, nearly $20 \%$ of all law schools still had no women on their faculties. ${ }^{268}$

Harvard Law continued to resist hiring women faculty. Between 1974 and 1981,

ten distinguished women taught at the Law School as visiting professors, a status often considered a stepping stone to a regular position. However, of the ten, only two were retained by the Law School; one was notified of this promotion during her visiting year, and the other was not offered a permanent position until eleven years after her visit. Perhaps the most famous woman to teach temporarily at Harvard Law School was now-Supreme Court Justice Ruth Bader Ginsburg, who was a lecturer on law in the fall of 1971 before accepting a tenured professorship at Columbia Law School. 269

One commentator explained: "[B]y the end of the 1970s the sight of a woman teaching in front of a law school classroom was not nearly as rare as it had been only a few years earlier." 270 Nevertheless, even as the number of women in law teaching would increase over the next fifteen years, their presence would continue to generate a perplexing amount of opposition in many law schools.

\section{IV. "BACKLASH" AND BEYOND: 1980-1996}

After the initial efforts to bring a few women into law school faculties in the '70s, some law schools seemed to believe that nothing more needed

266. Fossum, supra note 49 , at 906.

267. Weisberg, supra note 178, at 228. The fifteen schools were "Antioch, Capital, Cleveland-Marshall, McGeorge, Mercer, N.Y.U., North Carolina Central, Northeastern, Nova, Rutgers-Camden, Rutgers-Newark, Southern Illinois, Suffolk, [UC] Davis, University of Hawaii." Id. ("[P] rimarily progressive institutions, newly accredited law schools and some schools which may be labelled as "non-prestigious' law schools.").

268. Weisberg, supra note 178, at 230-31.

269. Basile, supra note 37 , at 144-45.

270. Fossum, supra note 49, at 913. 
to be done. Susan Prager (1942-), then dean at UCLA Law, admitted that "many of us, including myself, were lulled into feeling that no more efforts were needed." 271 Martha Field (1943-), a professor at Harvard, asserted that some schools thought that concern about hiring women was a "silly issue," and that "[a]t most schools, . . . in all good faith, . . . men on appointments committees are likely to think males are stronger candidates." 272

Many of the women who joined law faculties in the '70s and ' 80 s identified as feminists, and some were committed to developing a feminist critique of law. The first significant gathering of feminist scholars took place in Boston in 1985, as an outgrowth of the Critical Legal Studies (CLS) movement. Organized by Clare Dalton, Mary Joe Frug, Judi Greenberg, and Martha Minow, this "fem-crit" conference provided a vehicle for women to discuss issues that had been treated as largely irrelevant by many of their CLS colleagues. Indeed, Carrie Menkel-Meadow (1949-) recalled that "year after year the women at CLS conferences were relegated to their own ghettoized session (usually labeled 'Feminist Theory and the Law' and seldom attended by the men)." 273 Even after this successful conference, however, she noted that " $[\mathrm{s}]$ ome male critical theorists . . . felt the conference had been a 'diversion' from the critical legal studies agenda, and that now that the women had been given a chance to "do their own thing,' we should return to 'critical' work." 274 Instead, many feminist scholars continued to work together to develop a feminist critique of the law.

It is not surprising that many female law professors would have gravitated toward this area of study. They had often been marginalized themselves in the world of legal academia, which freed them to take a hard look at hierarchical systems that had contributed to their oppression. Many had experienced the worst form of bullying under the guise of Socratic questioning by hostile male professors. Not only did they seek to develop rigorous critiques of settled legal doctrine from a feminist perspective, but many feminist scholars also advocated for change in law schools themselves, arguing for revisiting archaic teaching methods, outdated curricula, and the stratification of positions in law schools by gender. In contrast to the earlier "Women and the Law" courses that had emerged in the '70s, new courses in "Feminist Jurisprudence" and "Feminist Legal Theory" started to enter the curriculum of law schools in the early 1980 s. $^{275}$

The battle over the value of a feminist critique of law took place against a highly charged conflict in legal academia between left and right,

271. Lauter, supra note 208.

272. $I d$.

273. Carrie Menkel-Meadow, Feminist Legal Theory, Critical Legal Studies, and Legal Education Or the Fem-Crits Go to Law School, 38 J. Legal Educ. 61, 63 (1988).

274. Id. at 65.

275. Patricia A. Cain \& Linda K. Kerber, Subversive Moments: Challenging the Traditions of Constitutional History, 13 Tex. J. Women \& L. 91, 94 (2003). 
pitting advocates of Critical Legal Studies against more traditional colleagues who rejected the entire concept as anti-intellectual. ${ }^{276}$ For some scholars, the mere concept of feminist jurisprudence inspired skepticism, if not rage. Although there were many thoughtful critiques of the scholarly works of the early feminist scholars, and disagreements among them, some male professors took a tone that could only be described as deliberately tendentious. One overwrought professor attacked "Big Sister" in a 1992 article that bemoaned the "the obscure ravings of . . . the radical feminist legal scholars," whose "words are often virtually incomprehensible, their writings filled with shrill jargon and polysyllabic gibberish-their voices as outraged as their messages outrageous." 277

During the 1980s and early 1990s, a series of high-profile denials of tenure to feminist legal scholars in a short period of time generated considerable publicity, raising concerns that these battles reflected a backlash against feminism generally and women in law teaching in particular. ${ }^{278}$ Whatever the merits of each of these decisions, the appearance of a purge of feminist scholars sent a chilling message about what areas of scholarly endeavor would be treated as acceptable by male faculty members.

Clare Dalton (1950-) was a prominent feminist scholar at Harvard Law School who had published a groundbreaking feminist critique of contract law in 1985. ${ }^{279}$ After a two-year postponement of her tenure application, purportedly for insufficient scholarship, the full faculty then voted to deny her tenure in 1987. She was only the second assistant professor in seventeen years to be denied that promotion. ${ }^{280}$ At the time of her tenure vote, the Harvard Law faculty consisted of fifty-two tenured men and five tenured women. ${ }^{281}$ Dalton immediately sued for sex discrimination and ultimately settled for $\$ 260,000$ and attorney's fees. ${ }^{282}$ That same year, the

276. See generally Mark Tushnet, Critical Legal Studies: A Political History, 100 YALE L.J. 1515 (1991).

277. Kenneth Lasson, Feminism Awry: Excesses in the Pursuit of Rights and Trifles, 42 J. Legal Educ. 1, 2-4 (1992). Catharine MacKinnon demanded a retraction of some of his claims as "libel." Catharine A. MacKinnon, Letter to the Editors, $42 \mathrm{~J}$. LegAL Educ. 465, 465 (1992). Lasson harrumphed in return. Kenneth Lasson, Comments in Reply, 42 J. Legal Educ. 467, 468 (1992).

278. See Nancy Levit, Keeping Feminism in its Place: Sex Segregation and the Domestication of Female Academics, 49 U. KAN. L. Rev. 775, 793-94 n.68 (2001); Sharon Elizabeth Rush, Understanding Diversity, 42 FLA. L. Rev. 1, 14-16 (1990) (discussing tenure battles of Professors Drucilla Cornell, Clare Dalton, and Lucinda Finley).

279. Ann Shalleck, The Feminist Academic's Challenge to Legal Education: Creating Sites for Change, 20 J.L. \& PoL'y 361, 364, 372 (2012); see Clare Dalton, An Essay in the Deconstruction of Contract Doctrine, 94 Yale L.J. 997 (1985).

280. Emily M. Bernstein, Bok Rejects Dalton Tenure Appeal, Harv. Crimson (Feb. 9, 2003), https://www.thecrimson.com/article/2003/2/9/bok-rejects-dalton -tenure-appeal-ppresident/ [https://perma.cc/J7JW-D4N3].

281. Head of Harvard Says No to Teacher's Tenure, N.Y. Times (Mar. 11, 1988), https://www.nytimes.com/1988/03/11/us/head-of-harvard-says-no-to-teacher-stenure.html [https://perma.cc/P35A-6J8W].

282. Carol Kleiman, Evidence Tenuous for Denied Tenure, ChI. Tris. (Oct. 14, 1993), https://www.chicagotribune.com/news/ct-xpm-1993-10-14-9310140190- 
University of Pennsylvania Law School denied tenure to feminist scholar Drucilla Cornell (1950-), despite one colleague arguing that "if a man had accomplished as much[,] . . . there would have been no question of tenure worthiness." 283 Other colleagues argued, however, that there was no evidence of sex discrimination, with one colleague contending that the increase in the number of women on the Penn faculty from only two in 1981 to seven in 1988 undermined any such contention. Although 400 students signed a petition on behalf of Cornell, she failed to overturn the adverse tenure vote against her. Soon thereafter, in 1990, feminist scholar Lucinda Finley left Yale after seven years on the faculty, after being informed that she would be denied tenure if she forced the question to a vote. ${ }^{284}$

Berkeley also found itself in the spotlight when its faculty denied tenure to two female professors, "due to perceived deficiencies in their scholarship." 285 In 1985, Marjorie Shultz lost her initial tenure battle, which she attributed in part to derisive views about her choice of subject matter. One colleague asserted that "her tenure article topic did not contribute much to scholarship since, "we already have one article on marriage contracts,'" and another openly inform[ed] her that "the whole topic bores and irritates me." 286 Publication on a related topic in the Yale Law Journal did not save her candidacy for tenure, although the university converted her position to a permanent lectureship in 1986.287 One year later, Eleanor Swift (1945-) also failed to obtain a favorable tenure vote and immediately filed a formal grievance with the Berkeley Privilege and Tenure Committee. In 1988, Swift announced that the Committee had found sufficient evidence of sex discrimination to merit a full hearing. ${ }^{288}$ Swift's case settled in December 1988, and by 1990, the law school reversed its positions as to both Shultz and Swift, who both were awarded tenured faculty positions. ${ }^{289}$

The travails of Catharine MacKinnon (1946-), perhaps the bestknown feminist law professor in the country, also served as a warning to

story.html [https://perma.cc/FDW5-ZELG]; see also Judy Mann, A Win for the 'Wrong Kind of Women,' WAsH. Post (Sept. 29, 1993), https://www.washing tonpost.com/archive/sports/1993/09/29/a-win-for-the-wrong-kind-of-women/ b01e5aec-c7bc-422d-b399-bb43a7c308d5/ [https://perma.cc/M2KP-8QEN].

283. Debra Cassens Moss, Would This Happen to a Man?, Ам. B. Ass'n J., June 1,1988 , at 50, 50. Cornell's tenure vote was ten for, six against, and one abstention, and thus just short of the necessary two-thirds required. Id.

284. Carter, supra note 44; see also Rush, supra note 278, at 14-18.

285. Kay, supra note 231, at 368.

286. Andrea Guerrero, Silence at Boalt Hall: The Dismantling of AfFirmative ACTION 50 (2002).

287. Id. at $50-52$.

288. Id.

289. See Kay, supra note 231; Eleanor Swift, Becoming a Plaintiff, 4 Berkeley Women's L.J. 245, 250 (1990); Eleanor Swift, Better Than Going to Court? Resolving a Claim of Discrimination Through a University's Internal Grievance Process, 29 BerkelEY J. GENDER L. \& Just. 337, 342 n.12 (2014). 
women faculty who might be considering nontraditional scholarship. MacKinnon's groundbreaking scholarship provided much of the underpinning for the Supreme Court's recognition of sexual harassment as a form of sex discrimination in 1986, and she had written prolifically for many years. Nevertheless, MacKinnon shuttled for years among the top law schools in the country, often amid controversy over her presence. At Yale Law, for example, noted ethics scholar Geoffrey Hazard "blasted her book Sexual Harassment of Working Women in a memo to the faculty," asserting that she lacked "genuine comprehension of law," in that she allegedly had failed to discuss tort law. ${ }^{290}$ After the chair of the appointments committee pointed out that her book contained ten pages on the tort law doctrine of sexual harassment, Hazard conceded that he had not read that section of her book, but adhered to his position that her work was nothing but "polemic."291 Eventually, MacKinnon obtained a tenured position at the University of Michigan Law School in 1989.292

The visibility of these controversies prompted a number of inquiries. In August 1987, the ABA appointed an eleven-member Commission on Women in the Profession to examine the "problems of gender bias" in the legal profession. The commission was headed by Arkansas lawyer Hillary Rodham Clinton (1947-), who chaired it until 1992. ${ }^{293}$ That commission held two days of hearings in Philadelphia, featuring about sixty witnesses focused on the status of women law professors. One participant described the testimony as "truly shocking." 294 Drucilla Ramey, executive director and general counsel for the Bar Association of San Francisco, stated:

290. Edward A. Adams, A Battle For Yale Law School's Soul?; Offer to A Feminist Draws Fury, 10 NaT'L L.J. 6, 6 (Feb. 15, 1988).

291. Id.; see also Frances Olsen, Feminist Theory in Grand Style, 89 Colum. L. Rev. 1147 (1989). For a discussion of the Yale opposition, see Adams, supra note 290 .

292. See Ron Grossman, Women Get High Marks, Low Tenure at Law Schools, CHI. TRIB. (June 23, 1989), https://www.chicagotribune.com/news/ct-xpm-1989-06-238902190382-story.html [https://perma.cc/D93L-GR72]. McKinnon recently recalled:

What people do is trim their sails in terms of content. They don't tell the truth about what's really happening to women, for example, so they get the job. It never occurred to me to do that. And even though I didn't get the jobs, there continued to be major fights about appointing me for two decades. The big exception was Michigan, a great school, which offered me a position with tenure. Wandering in the desert, as you put it, was my tenure process. And it turns out, in many of those years, I was the most frequently cited scholar writing in English on law. But nobody knew that because the studies hadn't been done yet.

Philip Galanes, Catharine MacKinnon and Gretchen Carlson Have a Few Things to Say, N.Y. Times (Mar. 17, 2018), https://www.nytimes.com/2018/03/17/business/ catharine-mackinnon-gretchen-carlson.html [https://perma.cc/PJF4-JLWW].

293. David Margolick, 2 Women Take Stage and Stir Bar Meeting, N.Y. Times (Aug. 10, 1992), https://www.nytimes.com/1992/08/10/us/2-women-take-stageand-stir-bar-meeting.html [https://perma.cc/MQV4-8G3K].

294. Grossman, supra note 292 (internal quotation marks omitted). 
[I]t is an absolute open secret among every single woman who teaches . . . in law school today that, in fact, the ordinary schlemiel from these elite law schools who got some clerkship is going to get tenure without too much trouble in our most distinguished schools, whereas women are scrutinized under a microscope and are generally found to be fatally flawed in one way or another. ${ }^{295}$

"The most-repeated horror story was the one about the male professor who told his class that he could no longer find a good maid or secretary because they were all in law school." ${ }^{296}$ In its report, issued in June 1988, the commission described the "persistence of discrimination against women faculty and students in law schools," explaining:

Testimony focused on incidents of sexual harassment and hostility directed against women professors and students, including increased appearances of pornographic graffiti and antagonistic comments in the classroom. Witnesses also voiced concerns about the small number of women rising to tenured positions on faculties, especially at the elite schools. A number of witnesses testified that the relative lack of attention to issues of importance to women in the curriculum sends a signal that women and their contributions to the legal profession are not important. It also discourages women faculty from producing scholarship about women. ${ }^{297}$

The AALS also began an investigation in November 1988, when President Herma Hill Kay announced the appointment of the Special Committee on Tenure and the Tenuring Process. Its lengthy report, issued in 1992, barely addressed issues of sex discrimination in the promotion of women law professors, although it noted that women tended to resign prior to tenure decisions at a statistically significant higher rate. ${ }^{298}$ The report urged blandly:

Until they achieve a certain critical mass on law school faculties, women and minority men may experience or feel isolation and alienation. They may also reflect different values and wish to pursue different forms or avenues of scholarship from those of traditional white male colleagues. Among questions in need of probing is how inclusive or exclusive are conceptions or defini-

295. Carter, supra note 44.

296. Id.

297. Am. Bar Ass'n Comm'n on Women in the Profession, Report to the House of Delegates 8-9 (1988); see also Angel, supra note 157, at 721 nn.19-20.

298. Report of the AALS Special Committee on Tenure and the Tenuring Process, $42 \mathrm{~J}$. Legal Educ. 447, 483 (1992). 
tions of scholarship in the formulation and administration of law school tenure standards and procedures. ${ }^{299}$

Although conditions had undeniably improved for women law professors in the ' 80 s and '90s, compared to the experiences of the prior generation, signs of persistent sex discrimination and backlash in law schools could not be ignored. One of the most shocking incidents during this period involved feminist law professor Mary Jo Frug (1941-1991). Frug began her teaching career at Villanova Law School in 1974 and became the first woman to receive tenure there. In 1981, Frug left Villanova and joined the faculty of New England School of Law in Boston. Frug had been one of the organizers of the first "fem-crit" conference in 1985, and she had begun to develop a feminist critique of contract law. ${ }^{300}$

In 1987, the AALS Committee on Women in Legal Education began planning its annual panel on "Sex Bias and the Teaching of" different substantive areas, which had previously included Criminal Law and Torts. As the Committee considered whether to focus its next panel on Contracts, Frug cautioned that the title of the panel should be modified "from Sex Bias in the Teaching of Contracts to Sex Bias in Contract Law-concerned about appearing to step on the feet of contracts professors and casebook authors who might be offended if they thought the critique was about them rather than about the law." ${ }^{01}$ Frug proved to be "prescient," as the male chair of the Contracts Section, David Slawson, was "totally opposed" to the idea and refused to cosponsor the panel. ${ }^{302}$ His publicly stated reason was that "the relationship between feminist theory and contract law was not 'developed . . . to a point where it is ready for such a sponsorship,' that it does not yet have 'a respectable basis." "303 Moreover, he argued that feminist theory could provide no insight in this area, because "the male bias of our society ... has not had important consequences for contract law." 304

The interest in addressing the intersection of gender with legal education could not be so easily dismissed. In 1988, the Journal of Legal Education published a lengthy symposium issue, "Women in Legal Education-

299. $I d$.

300. See Mary Joe Frug, Re-Reading Contracts: A Feminist Analysis of a Contracts Casebook, 34 Aм. U. L. Rev. 1065 (1985).

301. Patricia A. Cain, A Section Memoir, 80 UMKC L. Rev. 727, 732 (2012); see also Elizabeth Schneider, The AALS Section on Women in Legal Education: The Past and the Future, 80 UMKC L. REv. 733, 734 (2012).

302. Cain, supra note 301, at 732.

303. See Mary Joe Frug, Rescuing Impossibility Doctrine: A Postmodern Feminist Analysis of Contract Law, 140 U. PA. L. Rev. 1029, 1029 (1992) (citing Letter from W. David Slawson, Professor of Law, University of Southern California, to Mary Joe Frug, Professor of Law, New England School of Law 1-2 (June 24, 1988) (on file with the University of Pennsylvania Law Review)).

304. Id. at 1030 (internal quotation marks omitted) (quoting Letter, Mary Jo Frug, supra note 303 , at 3 ). 
Pedagogy, Law, Theory and Practice." 305 Soon thereafter, following up on the thwarted efforts of the previous year, the WLE Committee presented a panel on contracts called "The Influence of Feminist Theory and GenderBias in Contracts" at the AALS annual meeting in January 1989, which featured Frug, Clare Dalton, Marjorie Schultz, and other feminist scholars. Once again, the contracts section refused to co-sponsor the panel. ${ }^{306}$ At that panel, Frug presented a paper which would later be published as Rescuing Impossibility Doctrine: A Postmodern Feminist Analysis of Contract Law. ${ }^{307}$ In her remarks, she described what she considered to be the traditional male defense of the impossibility doctrine: "Like a phallus, this conceptual proposal is singular, daunting, rigid, and cocksure[,]" a metaphor that entertained the crowd, but proved disturbing to some male law professors. ${ }^{308}$

Frug would not live to finish this paper. On April 4, 1991, she left the home in Cambridge that she shared with her husband, Harvard Law professor Gerald Frug, and their children, to go for a walk. She never returned home, as she was brutally knifed to death on the street by an unknown assailant, in a crime that remains unsolved today. ${ }^{309}$ Her husband devoted himself to completing the scholarly work that she had left behind, ultimately producing six articles and a casebook. ${ }^{310}$

The shock of Frug's murder would soon give way to greater outrage. Less than a year after her death, in March 1992, the Harvard Law Review published her article, A Postmodern Feminist Legal Manifesto (An Unfinished Draft), which had been completed by her husband. ${ }^{311}$ The publication of this article apparently upset and offended some male students on the Harvard Law Review. Two students, Craig Coben and Kenneth Fenyo, prepared what they considered to be a parody of her article and distributed it to the attendees at the annual law review dinner, which happened to be held on the first anniversary of Frug's murder. Their handiwork, a "savage

305. 38 J. Legal Educ. (1988).

306. Schneider, supra note 301, at 734 .

307. 140 U. PA. L. Rev. 1029 (1992).

308. See id. at 1034-35. On a personal note, I attended Frug's presentation of this paper at the 1989 AALS conference during my first year as a law professor. When I returned to Villanova, I described Frug's talk to several of my male colleagues, all of whom knew Frug well from her days on the Villanova faculty, and quoted this statement on impossibility doctrine. I can only describe their reaction as horror that someone they had liked so much personally could ever have said such an outrageous and ridiculous thing in public. Their horror was clearly multiplied by hearing these dreadful words repeated to them over an otherwise pleasant lunch by a young female colleague.

309. Alan Wirzbicki, Killed Off Campus, Bos. Globe, https://apps.boston globe.com/true-crime/killed-campus/ [https://perma.cc/5E28-YFTX] (last visited May 21, 2020).

310. Gerald Frug, Mary Joe Frug, 50 New EnG. L. Rev. 273, 274 (2016).

311. Mary Joe Frug, A Postmodern Feminist Legal Manifesto (An Unfinished Draft), 105 Harv. L. Rev. 1045 (1992). 
mockery" entitled "He-Manifesto of Post-Mortem Legal Feminism," was signed "Mary Doe, Rigor-Mortis Professor of Law."312

The parody mocked Frug's word choice, suggested that Frug was unfashionable and dour, described her husband as a wimp while at the same time implying that her article was published only because her husband was a Harvard Law School professor, and shockingly stated that women's proper place was in the home. ${ }^{313}$

The incident made national news. Despite the insistence by some students and professors that the law school should take action to discipline the students for their actions, others contended that criticizing Harvard for not punishing the students had contributed to the "atmosphere of a McCarthyite witch hunt." 314 The Harvard Law faculty at that time was more than $92 \%$ male and was about to extend tenured positions to four white men after years of ideological deadlock within the faculty. ${ }^{315}$ Possibly in response to the turmoil over the law review dinner fiasco, the faculty made offers to five men and one woman. ${ }^{316}$ In light of these events, many feminist scholars worried that their field of study had become a lightning rod for those who resisted not only their critique of traditional legal scholarship but their very presence in the legal academy. ${ }^{317}$

Another highly publicized controversy that shook the confidence of many female law professors was the treatment of Professor Anita Hill (1956-), then on the faculty of the University of Oklahoma Law School, during the contentious confirmation hearings on the appointment of Clarence Thomas to the Supreme Court in the fall of 1991. Hill testified that Thomas had sexually harassed her during her time as his employee when he was the chair of the Equal Employment Opportunity Commis-

312. Linda R. Hirshman, Sex and Money: Is Law School a Dead-End Street for Women?, 87 Nw. U. L. Rev. 1265, 1266 (1993) (internal quotation marks omitted); see also Susan Conwell, Opinion, Sexist Cruelty Strikes at Harvard Law, Legal Times, Apr. 27, 1992, at 24. For an overview of the controversy, see Eleanor Kerlow, Poisoned Ivy: How Egos, Ideology and Power Politics Almost Ruined Harvard LAW SCHOOL 69 (1994).

313. Laura A. Rosenbury, Channeling Mary Joe Frug, 50 New Eng. L. Rev. 305, 307 (2016).

314. Fox Butterfield, Parody Puts Harvard Law Faculty in Sexism Battle, N.Y. Times (Apr. 27, 1992) (internal quotation marks omitted), https:// www.nytimes.com/1992/04/27/us/parody-puts-harvard-law-faculty-in-sexism-battle.html [https://perma.cc/F2F8-VXW6]; see also Harvard Will Not Punish Students Who Mocked Slain Law Professor, N.Y. Times (May 23, 1992), https:// www.nytimes.com/1992/05/23/us/harvard-will-not-punish-students-who-mockedslain-law-professor.html [https://perma.cc/PE9H-T2CR].

315. Hirshman, supra note 312, at 1267; Conwell, supra note 312.

316. Hirschman, supra note 312, at 1267 n.12 (first citing Ken Myers, Two Controversial Incidents Said to Spotlight Harvard Woes, NAT'L L.J., May 25, 1992, at 4; then citing Thomas Palmer, The Not So Civil War at Harvard Law School: Revue Parody Lays Bare Deeper Divisions, Bos. Globe, Apr. 26, 1992, at 74). (1991).

317. See Patricia Cain, Feminist Legal Scholarship, 77 Iowa L. Rev. 19, 29-39 
sion. She was vilified in the Senate and in the press for her testimony, branded a liar and a slut, and eventually her testimony was either ignored or rejected. Thomas categorically denied every one of her allegations under oath, and he was confirmed by a narrow majority of 52-48 on October $15,1991$.

The spectacle of a young, African-American, female law professor under ferocious public attack for reluctantly bringing forward accusations of sexual harassment prompted much concern among female law professors. The issue of sexual harassment in law schools had received limited attention in the past. In 1983, Dean Geoffrey W. Peters of William Mitchell Law School resigned during an investigation prompted by the complaints of eleven women employees at the school. ${ }^{318}$ More recently, in March 1991, thirteen women at Emory Law School filed complaints with the administration, charging that Professor Abraham P. Ordover had kissed them without their consent or called them at home and asked them for dates. After a university committee cleared him despite a finding of "inappropriate conduct," students protested the result, and four additional complaints were filed. Ordover resigned in April 1991.319

Shortly before the Thomas confirmation hearings, the Women in Legal Education Section of the AALS had been preparing a questionnaire to investigate the prevalence of sexual harassment in law schools. In the aftermath of the hearings, which prompted a national conversation about sexual harassment, section leaders turned instead to the task of attempting to develop a model policy to combat harassment. Achieving consensus on that issue proved to be more difficult than many women might have anticipated. The greatest conflict emerged over whether or not to advocate for a flat ban on all sexual relationships between students and faculty, with some women professors arguing that consent was illusory in such situations, while others insisted "that a complete ban failed to recognize the importance of honoring the agency of students who chose to have relationships with their professors." 320 The process of pursuing consensus on sexual harassment policies would proceed in fits and starts for at least the next ten years, and ultimately would produce an interim report but not a model policy. ${ }^{321}$

318. Law School Dean Quits in Sex Harassment Case, N.Y. Times (Nov. 8, 1983), https://www.nytimes.com/1983/11/08/us/around-the-nation-law-school-deanquits-in-sex-harassment-case.html [https://perma.cc/2REU-XW3J].

319. Ken Myers, Emory Professor Takes Leave Amid Charges of Harassment, NAT'L L.J. (Apr. 8, 1991); Emory Teacher Quits Amid New Sex Charges, N.Y. Times (Apr. 2, 1991), https://www.nytimes.com/1991/04/02/us/emory-teacher-quits-amid-newsex-charges.html [https://perma.cc/FQ6W-ZFTR].

320. Joyce McConnell, Memory or Imagination: Reflections on the Section on Women in Legal Education, 80 UMKC L. REv. 779, 784 (2012) (2000 WLE Chair); see also Karen Syma Czapanskiy, 1992: A Year of Women, Bravery, and Growth, 80 UMKC L. Rev. 751, 751 (2012).

321. Judith Maute, From Whence We Came and Where We Might Go, 80 UMKC L. Rev. 771, 774 (2012). 
Anita Hill's experience also brought to the forefront the persistence of discrimination against black female law professors. She later wrote of the hostility she experienced during her early years at Oklahoma Law. ${ }^{322}$ The number of black women in law teaching had increased somewhat, but it still remained small. As of 1994, they comprised only 3.5\% of all law professors. ${ }^{323}$ Many African-American women found the experience of teaching in law schools that were overwhelmingly white and male to be difficult. In response to these experiences, black women law faculty had begun to meet collectively. In March 1988, sixteen black women held a discussion group that later became the Northeast Corridor Collective, founded by Georgetown Law professor Emma Coleman Jordan. ${ }^{324}$ As of 2001, "only 4 percent of full professors and 1 percent of [law] deans [were] women of color." 325

Harvard Law School's failure to have ever granted tenure to any black female law professor erupted in turmoil in the academic year 1989-1990. Derrick Bell, the first African-American professor on the Harvard Law faculty, announced in the fall of 1989 that he would take a leave of absence until Harvard appointed a woman of color to its faculty. At the time, Regina Austin of the University of Pennsylvania Law School was a visitor at Harvard Law. Bell's announced protest was widely viewed as an attempt to put pressure on Harvard Law to extend an offer of a tenured position to Austin. The ideological divide within the faculty, coupled with intense debate over affirmative action, had already produced a difficult hiring atmosphere. Bell's well-publicized campaign ultimately did not succeed, as Austin did not receive an offer from Harvard Law. Black women faculty were divided over Bell's efforts, particularly because he had not consulted with Austin before taking such dramatic action on her behalf. Some felt gratitude for the steps he took, but others found his actions "patronizing." Bell soon left Harvard Law and spent the remainder of his career at New York University Law School. It would not be until 1998 that Lani Guinier (1950-) would become the first African-American woman to serve as a tenured member of the Harvard faculty. ${ }^{326}$

In light of the many roadblocks that persisted, it is not surprising that many women in legal academia worried about whether to identify themselves as feminists. The 1982 chair of the WLE section recalled: "Even being identified as an active Section member conveyed an implicit message to deans and more traditional male colleagues that this was a potential troublemaker who would not ignore gender stereotypes or discrimination in her own institution."327 Deborah Rhode (1952-) re-

322. See Anita Hill, Speaking Truth to Power (2007).

323. WATsON, supra note 141 , at 50.

324. Id. at 7 .

325. Rhode, supra note 98 , at 475.

326. See Watson, supra note 141, at 127; Jordan, supra note 141, at 4-6.

327. Myrna S. Raeder, Reflections About Who We Were When Joining Conveyed a Message, 80 UMKC L. REv. 703, 703 (2012). 
ported that her dean had advised her not to teach a course on gender discrimination:

His view was that nothing was lower on the academic pecking order, and worse still that if I taught or did research in the area, I would be typed "as a woman." I told him I didn't think that would come as a surprise. The point was that gender discrimination just wasn't a serious subject. ${ }^{328}$

Judith Resnik recalled that she had been advised when she began her teaching career: "Be careful. Don't teach in any areas associated with women's issues. Don't teach family law, don't teach sex discrimination. Don't teach trusts and estates. Teach the real stuff, the hard stuff: contracts, torts, procedure, property-and don't be too visible on women's issues." 329

Another source of tension as women entered law teaching in greater numbers was the continued trend of gender stratification in legal academia, especially in the area of legal writing. Legal writing courses in law schools had traditionally received short shrift, with many of them taught by part-time or adjunct faculty. Teaching legal writing was considered to be less prestigious and rigorous than teaching traditional substantive courses. As law school enrollment increased dramatically in the $1970 \mathrm{~s}$ and 1980s, many law schools needed additional faculty to teach legal writing, and were often more willing to hire women to teach those courses than to hold full-time tenure track positions. In the 1986-1987 academic year, for example, $68 \%$ of contract legal writing faculty were women. ${ }^{330}$

Over time, the gender skew in legal writing became increasingly pronounced, and by 2000 , the statistics were undeniable. One researcher described the "startling picture" in law schools: "the top jobs are overwhelmingly male, and the bottom ones are overwhelmingly female."331 He further noted: "[A]s soon as the field became large enough to be considered an underclass, it was stereotyped as female-a situation that continues to this day." 332 As a male legal writing director commented:

Far too many deans and faculty members assume that only women will take the law school jobs requiring intensive individualized teaching or mentoring of students. They further assume that women are more suited for such roles. Others will be very frank about their interests in improving the school's apparent

328. Cassens Moss, supra note 283, at 52.

329. Judith Resnik, Visible on "Women's Issues," 77 Iowa L. Rev. 41 (1991).

330. Richard H. Chused, Hiring and Retention of Minorities and Women on American Law School Faculties, 137 U. PA. L. Rev. 537, 557 (1988).

331. Richard K. Neumann Jr., Women in Legal Education: What the Statistics Show, 50 J. Legal Educ. 313, 323 (2000).

332. Id. at 326. 
gender balance by recruiting women for second-class-status positions in administration or teaching. I have lost count of the number of times I've heard people say things like "Can't we just find and hire a few bright women in town who have left practice to have babies?" Many assume that the second-class jobs should be filled by the second wage earner in the family, and they determine pay accordingly. They believe that a woman who does the job well either will do it for a short time before returning to practice or will do it longer and not move on because family commitments make her geographically immobile, and that in either case she will accept the lower pay and not challenge the inequities of her position for fear of losing her job to another, also fungible, replacement. The statistics bear out the widespread prevalence of these beliefs, whether consciously or unconsciously held. ${ }^{333}$

As the statistics indicated:

Wherever jobs exist off the conventional tenure track, women are being hired into them at very high frequencies, and at those same schools proportionately fewer women are being hired onto the conventional tenure track. . . . The same pattern occurs in other ways in legal education, as lesser jobs-assistant deans and nondirector librarians, for example-are gender-stereotyped as female while the jobs above them on a status ladder have been variable or gender-stereotyped as male. ${ }^{334}$

At a time when $75 \%$ of doctrinal professors were male, it was even more striking how the lower status and pay for legal writing affected an overwhelmingly female population. ${ }^{335}$

One example comes from within the field of legal writing: of the more than 500 teachers, about 70 percent are women, but men have almost half of the tenured positions. The situation is similar for law librarians. Out of 930, 65 percent are women. Of the 90 who hold teaching and tenure-track positions in law schools (as compared to tenure in a law library), more than half (53\%) are by men. ${ }^{336}$

As Marina Angel later explained: "Women got in the door of legal education, but many have found themselves in the basement of a redesigned building." 337 The question of how to rectify the unequal treatment of le-

333. Id. at 347 .

334. Id. at 346 .

335. See Jo Anne Durako, Second-Class Citizens in the Pink Ghetto: Gender Bias in Legal Writing, 50 J. Legal Educ. 562 (2000).

336. Judith Resnik, A Continuous Body: Ongoing Conversations about Women and Legal Education, 53 J. Legal Educ. 564, 568 n.19 (2003).

337. Marina Angel, The Glass Ceiling for Women in Legal Education: Contract Positions and the Death of Tenure, 50 J. Legal Educ. 1, 2 (2000). 
gal writing faculty would receive greater attention in later years, but it remains today among the most visible aspects of gender inequality in law schools.

In an attempt to pursue broader solutions to sex discrimination in law schools, in 1989 the Section on Women in Legal Education of the AALS began a concentrated effort to include issues relating to female faculty in the accreditation standards utilized by the AALS to assess law schools:

[A] focus on written policies on promotion, retention, and tenure; a job description upon appointment; a system of ongoing peer support; yearly evaluations of teaching, scholarship, and service; avoiding too many responsibilities for junior faculty; appropriate teaching loads and committee service; adequate support for research; recognition that women and minority faculty are given additional demands; reasonable leave for disability and pregnancy; nondiscrimination on the basis of research topic; and a sexual harassment policy. ${ }^{338}$

Unable to convince the AALS leadership to include these issues in the formal standards, in 1994 the WLE instead sought permission to circulate a "Statement of Good Practices," to law deans. They received limited permission "to distribute the views (under some label other than Statement of Good Practices) to members of the Section and deans, so long as any distribution contains the usual disclaimer language applicable to positions taken by individual sections." 339 Watering down the standards in this way was "frustrating," but at least placed the issues on the table for site teams to consider. ${ }^{340}$

In retrospect, one wonders how much actual change these bureaucratic task forces and committees could realistically have accomplished. Nevertheless, in 1996, the ABA Commission on Women in the Legal Profession issued yet another report, entitled "Elusive Equality: The Experiences of Women in Legal Education," based on testimony from women at nearly sixty law schools. ${ }^{341}$ Despite the fact that $44 \%$ of law students and about $28 \%$ of law faculty were female, the Report found that the substantial increase in numbers of women law students and faculty had not necessarily diminished the pervasiveness of open hostility and subtle barriers to equal treatment. Sylvia Law noted:

There are young men who don't like the idea of a female authority figure and do what they can to undermine that authority ....

338. Rothstein, supra note 163 , at 762-63.

339. Id. at 763 (internal quotation marks omitted) (quoting Letter from Carl Monk, AALS Exec. Dir., to Laura Rothstein, WLE Section Chair (May 17, 1994) (copy on file with author)).

340. Maute, supra note 321, at 772-73.

341. Am. Bar Ass'n Comm'n on Women in the Profession, Elusive Equality: The Experiences of Women in Legal Education 32-33 (1996). 
They sit in the back and create that little cackle section. Almost every female teacher has experienced that. It doesn't take that many to poison the atmosphere in a large class. ${ }^{342}$

The report also found that many female teachers believed they are ghettoized in certain teaching assignments, that major faculty committees have no women representatives, and that few women hold endowed chairs. The report made several recommendations: that each school create a committee on gender issues; that faculty members examine their courses, teaching methods, and textbooks to make sure issues important to women are included and handled appropriately; that students treat other students with respect and pressure administrators and other students for change; and that deans pay more attention to gender issues, hire and promote more women, include more women on powerful committees, and eliminate gender disparities in pay. ${ }^{343}$ The report expressly identified the area of legal writing as a "pink ghetto." 344

In 1996, after 100 years of women teaching law, discrimination on the basis of sex within legal academia remained an intractable reality. Although it is undeniable that much progress had been made in the latter part of the twentieth century, the extent of the problem remained largely unexplored in any systematic way, and the next twenty-five years would see new challenges arise for the next generation of women in law schools. But for now, this is where the story of the first century ends.

\section{Conclusion}

As the articles in this Symposium Issue demonstrate, there remains much to be done to ensure full gender equity in legal academia. It will be essential for women in law teaching today to prioritize this struggle, to pave the way for the next generation, as past generations paved the way for us. There is nothing we cannot achieve if we remember Susan B. Anthony's famous battle cry from her final speech in 1906: "Failure is impossible."

342. Ken Myers, Bias Against Women Lives On, Hearings and ABA Study Show; Law Schools, 18 NAT'L L.J. 1 (1996).

343. Id.

344. Neumann Jr., supra note 331, at 326 (internal quotation marks omitted) (quoting Am. Bar Ass' ' Comm. on Women in the Profession, supra note 341, at 32-33). 